\title{
Roles of adenine methylation and genetic mutations in adaptation to different temperatures in Serratia marcescens
}

\author{
Matthieu Bruneaux ${ }^{1 * \dagger}$, Ilkka Kronholm ${ }^{1 *}$, Roghaieh Ashrafi ${ }^{1}$, \\ Tarmo Ketola ${ }^{1}$
}

March 11, 2021

${ }^{1}$ Department of Biological and Environmental Science, University of Jyväskylä, Finland * Joint first authors

${ }^{\dagger}$ Author for correspondence: Matthieu Bruneaux, Department of Biological and Environmental Science, University of Jyväskylä, Finland (matthieu . bruneaux@ens-lyon .org).

Running title: "Roles of genetics and epigenetics in adaptation" 
Epigenetics and adaptation

\begin{abstract}
Epigenetic modifications can contribute to adaptation, but the relative contributions of genetic and epigenetic variation are unknown. Previous studies on the role of epigenetic changes in adaptation in eukaryotes have nearly exclusively focused on cytosine methylation $(\mathrm{m} 5 \mathrm{C})$, while prokaryotes exhibit a richer system of methyltransferases targetting adenines $(\mathrm{m} 6 \mathrm{~A})$ or cytosines $(\mathrm{m} 4 \mathrm{C}, \mathrm{m} 5 \mathrm{C})$. DNA methylation in prokaryotes has many roles, but its potential role in adaptation still needs further investigation. We collected phenotypic, genetic, and epigenetic data using single molecule real-time sequencing of clones of the bacterium Serratia marcescens that had undergone experimental evolution in contrasting temperatures to investigate the relationship between environment and genetic, epigenetic, and phenotypic changes. This data provided a detailed description of the methylation landscape of $S$. marcescens and allowed us to examine the potential contributions of genetic and epigenetic changes to phenotypic adaptation. The genomic distribution of GATC motifs, which are the main target for m6A methylation, and of partially methylated epiloci pointed to a link between m6A methylation and regulation of gene expression in S. marcescens. Evolved strains, while genetically homogeneous, exhibited many polymorphic m6A epiloci. There was no strong support for a genetic control of methylation changes in our experiment, and no clear evidence of parallel environmentally-induced or environmentally-selected methylation changes at specific epiloci was found. Both some genetic and epigenetic variants were associated with some phenotypic traits. Overall, our results suggest that both genetic and adenine methylation changes have potential to contribute to phenotypic adaptation in S. marcescens, but that any environmentally-induced epigenetic change occurring in our experiment would probably have been quite labile.
\end{abstract}

Keywords: Experimental evolution, methyltransferase, single molecule real-time sequencing. 


\section{Introduction}

30 While the traditional view of evolution is that adaptation proceeds via changes in DNA sequences, any heritable phenotypic variation can in principle be subject to natural se-

32 lection. In recent years, some epigenetic changes such as DNA methylation changes have been found to be heritable and could thus theoretically play a role in evolution

34 (Jablonka and Raz, 2009; Day and Bonduriansky, 2011; Danchin et al., 2011; Kronholm and Collins, 2016; Danchin et al., 2019). However, even if convincing cases of epige-

36 netic inheritance have been documented (Cortijo et al., 2014), the role of epigenetic variation in evolution has been met with some skepticism (Charlesworth et al., 2017),

38 the main argument for caution being that despite frequent observations we know very little about the relative contributions of genetic and epigenetic variation to adaptation.

40 Addressing this question requires the simultaneous characterization of genetic, epigenetic and phenotypic changes in a population, which remains extremely challenging in

42 a natural system, and so far empirical results have lagged behind theoretical models. Experimental evolution under controlled laboratory conditions with bacteria that have short generation times and large population sizes provides the opportunity to study this question in a practical way.

Non-genetic inheritance encompasses various mechanisms, such as structural inheritance via propagating templates (e.g. prions), self-sustaining regulation loops and DNA methylation (Jablonka and Raz, 2009). DNA methylation is particularly well studied and exists both in eukaryotes and in prokaryotes. While DNA methylation

50 can have phenotypic effects in both of those taxonomic groups, important differences exist between them. In eukaryotes, C5-methylcytosine (m5C) is the best known mod-

52 ification and occurs in CpG-rich regions. Genome methylation patterns are maintained after DNA replication via maintenance methyltransferases but DNA methy-

54 lation can be reset in the germ line. In prokaryotes, N4-methylcytosine $(\mathrm{m} 4 \mathrm{C})$ and N6-methyladenine (m6A) are known in addition to m5C (Ratel et al., 2006; Casadesús 56 and Low, 2006). Methylation is lost on the newly synthetized DNA strand during 
replication, and methylation restoration depends on the activity of sequence-specific 58 methyltransferases after passage of the replication fork.

DNA methylation systems in prokaryotes are very diverse and include restriction60 modification (RM) systems and orphan methyltransferases (MTases). RM systems associate an MTase activity and a complementary endonuclease activity: methylation

62 of the target sequence protects DNA from restriction. Orphan MTases do not have an associated restriction enzyme but are thought to be evolutionary derived from RM

64 systems. DNA methylation in bacteria has a wide range of well-documented roles: protection against foreign DNA via RM systems, regulation of DNA replication and

66 mismatch repair based on hemimethylated DNA, control of mobile elements and regulation of gene expression (Casadesús and Low, 2006; Sánchez-Romero et al., 2015).

68 Crucially, DNA methylation patterns can be inherited in prokaryotes: orphan MTases can compete with other regulatory proteins for access to cognate DNA sequences, for

70 example in promoter and regulatory regions, resulting in self-regulating loops that can be maintained across cell division (Braaten et al., 1994).

72 We used Serratia marcescens as a bacterial model in evolution experiments and characterized genetic, epigenetic and phenotypic differences between strains evolved

74 from a common ancestor culture. S. marcescens is an opportunistic pathogen which can live in a variety of environments, including inside insect and mammalian hosts,

76 with an optimal growth temperature close to $31^{\circ} \mathrm{C}$ (Grimont and Grimont, 1978; Flyg et al., 1980; Ketola et al., 2013). S. marcescens possesses a Dam MTase targeting 78 adenines in $5^{\prime}$-GATC-3' motifs, and it has been shown that this enzyme is important to enable the mismatch repair machinery to distinguish between the original and the 80 new DNA strand during replication (Ostendorf et al., 1999; Blow et al., 2016).

While examples of inherited epigenetic changes and their involvement in bacterial 82 adaptation exist (Adam et al., 2008; Atack et al., 2015), we do not fully understand yet the relative importance of epigenetic and genetic variation in evolution. Here, we

84 studied the role of epigenetics in evolution in a prokaryotic system by (1) characteriz- 
Epigenetics and adaptation

ing the epigenetic variation related to $\mathrm{m} 6 \mathrm{~A}$ in Serratia marcescens after evolution in different conditions, (2) determining if the observed epigenetic variation was associated with specific environmental conditions, and (3) comparing the potential contributions of epigenetic and genetic variation to phenotypic variation.

We addressed these questions by phenotyping and single-molecule real-time (SMRT)

90 sequencing of bacterial strains from an evolution experiment conducted at three contrasting thermal regimes: $31^{\circ} \mathrm{C}$ constant, $38^{\circ} \mathrm{C}$ constant, and $24-38^{\circ} \mathrm{C}$ fluctuating

92 environments (Ketola et al., 2013). By introducing a common garden step before phenotypic measurements and DNA sequencing, we focused on the identification of

94 evolutionary differences in methylation patterns which would be stable enough to be propagated across several generations after their establishment once selection pressure was relieved and we ignored epigenetic mutations with fast back-mutation rates which would be more akin to phenotypic plasticity. Additionally, to investigate the mechanism by which adenine methylation could affect cell processes in $S$. marcescens, we examined if the genomic distribution of the GATC cognate motif exhibited any 100 informative pattern.

\section{Materials and Methods}

\section{Experimental evolution and phenotypic measurements}

We used bacterial strains that were obtained from a previous evolution experiment

104 (Ketola et al., 2013). To summarize this experiment briefly, we let populations of Serratia marcescens initiated from a single common ancestor colony evolve under either constant or fluctuating temperatures during three weeks (treatments: constant $31^{\circ} \mathrm{C}$, constant $38^{\circ} \mathrm{C}$ or alternating daily between $24^{\circ} \mathrm{C}$ and $38^{\circ} \mathrm{C}$ ) (Ketola et al., 2013)

108 (Supplementary Figure S1). Note that lines evolved in $38^{\circ} \mathrm{C}$ were not reported in Ketola et al. (2013). The experiment lasted approximately 70 generations (based on 110 1/10 daily subcultures for 3 weeks). Given that population sizes were of the order of 
Epigenetics and adaptation

$8 \times 10^{6}$ cells in each $400 \mu \mathrm{L}$ culture well at plateau, and that the fraction transferred

112 to the next generation was 1/10 of the previous culture, the effective population size is estimated to be $N_{e}=2.6 \times 10^{6}$ during the experiment (using $N_{e}=N_{0} g$ from Lenski

114 et al. (1991), where $N_{0}=8 \times 10^{5}$ cells is the bottleneck size and $g=3.3$ is the number of generations between transfers). After experimental evolution, individual colonies

116 were isolated from each population by plating and stored at $-80{ }^{\circ} \mathrm{C}$ in $50 \%$ glycerol.

We randomly selected one frozen clone from each population for sequencing (10

118 from the $31^{\circ} \mathrm{C}$ treatment, 8 from the $38^{\circ} \mathrm{C}$ treatment and 10 from the fluctuating treatment, i.e. 28 evolved strains sequenced in total). As a reference and since the

120 frozen stocks for the common ancestor itself could not be revived successfully prior to sequencing, we also sequenced the stock strain from ATCC (ATCC 13880) from which

122 the common ancestor colony was derived (Supplementary Figure S1). This strain is referred to as the "reference strain" in the rest of this manuscript. We used the

124 phenotypic data from Ketola et al. (2013) (Supplementary Figure S2), which included measurements of growth rate and yield at constant $24^{\circ} \mathrm{C}, 31^{\circ} \mathrm{C}$ and $38^{\circ} \mathrm{C}$ for the

126 evolved strains. In addition, growth rate and yield had been measured in a series of novel environments: under redox balance stress $(1 \mathrm{mg} / \mathrm{ml}$ dithiotreitol $)$, in the presence

128 of the ciliate predator Tetrahymena thermophila and in the presence of a virus, the lytic bacteriophage PPV. For further details on these phenotypic measurements, see Ketola 130 et al. (2013).

\section{Sequencing and genome annotation}

132 Sequencing We used single molecule real-time sequencing (SMRT) with the PacBio platform to sequence the evolved strains and the reference strain. Since no template

134 amplification takes place prior to sequencing on a PacBio platform in order to detect base modifications, relatively large amounts of DNA per strain are necessary with

136 this method. Evolved strains were thawed and grown overnight in $150 \mathrm{ml}$ of liquid medium and DNA was extracted using the Wizard Genomic DNA Purification Kit 
Epigenetics and adaptation

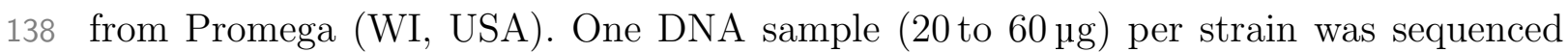
by the DNA Sequencing and Genomics Laboratory of the University of Helsinki on a

140 PacBio RS II sequencing platform using P6-C4 chemistry. Two single-molecule realtime sequencing (SMRT) cells were run per DNA sample.

142 PacBio software and recommended protocols were used with default parameters for the assembly and modification calling pipeline. For each strain, reads from the RS

144 II instrument were assembled with PacBio RS_HGAP_Assembly.3, as implemented in SMRTportal 2.3.0. The resulting assembly for each strain was processed with the Gap4 146 program to generate de novo a first draft sequence for this strain and to circularize it. PacBio RS_Resequencing. 1 protocol was then run 2 to 3 times for each sample to map

148 the reads to the draft sequence and generate a consensus sequence for each strain. The average coverage of the draft chromosome per strain was high (from 102 to 413, average

150268 across all strains). We used Samtools (version 1.7, Li et al. (2009)) to examine PacBio reads mapped back to their respective assemblies in order to check for evidence

152 of polymorphism within each sequenced strain. Such polymorphism would indicate that a given strain would be comprised of several genetic clones, which is possible if 154 an isolated colony grew from more than a single isolated cell. Based on the Samtools pileup files, the distribution of proportions of mismatches for each position within a

156 strain was compatible with the expected base error rate for PacBio SMRT sequencing (about 11-15\%, Rhoads and Au (2015)), except for a short ca. 700bp region comprised

158 of repeated sequences and which was ignored in downstream analyses. Given the high coverage of the chromosome sequences across all strains, the base calling was considered

160 accurate outside of this repeat region and genetic variants were directly called from an alignment of the 29 assembled chromosomes built with Mugsy (Angiuoli and Salzberg, 162 2011).

Estimation of methylated fractions Inter-pulse duration (IPD) ratios were used 164 with the PacBio RS_Modification and Motif_Analysis protocol to detect modified 
bioRxiv preprint doi: https://doi.org/10.1101/822080; this version posted March 11, 2021. The copyright holder for this preprint (which was

Epigenetics and adaptation

bases and identify methylation sequence motifs. Methylated adenines (m6A) are the modified bases with the strongest kinetic signal (Clark et al., 2012) and we only analysed those modifications in downstream analyses. Before downstream analysis, we 168 applied a quality value threshold of 20 (i.e. $p$-value $\leq 0.01$ ) for the event detection score, which is a Phred-like quality score defined as $Q=-10 \log _{10}($ pval $)$. For detected

170 events, a second quality score is available for modification identification (m6A or other modification type). Since the identification quality score depends on the methylated

172 fraction (lower fractions yielding lower scores), we accepted identifications as m6A for a given position in all strains if the identification quality score at that position was $\geq$

17420 in at least one strain. We did this to avoid being over-conservative and underestimating the methylated fractions for positions which were likely to be truly methylated

176 but with a low methylation fraction in some strains. We checked that the ability to estimate low methylation fractions for m6A was not impaired in strains with the lowest

178 coverages by examining the relationship between coverage and m6A fraction in GATC motifs (Supplementary Figure S3).

180 Genome annotation We used the NBCI Prokaryotic Genome Annotation Pipeline (PGAP, Tatusova et al. (2016), version 2020-09-24.build4894) to annotate the assem-

182 bled genome of our reference strain. The location of the origin of replication was determined using the DoriC server (Gao et al., 2012). The CDS predicted by PGAP

184 were assembled into operons using the Operon Mapper server (http://biocomputo. ibt.unam.mx/operon_mapper/, Taboada et al. (2018), run on 2020-12-07). Gene ontology annotations for the CDS predicted by PGAP were pooled from two approaches: (i) submitting the predicted CDS to Interproscan (Jones et al. (2014), ver-

188 sion 5.48-83.0) and (ii) running a tblastn search of the predicted CDS against all UniProtKB entries related to Serratia marcescens (UniProtKB database searched via 190 https://www. uniprot.org/ on 2019-01-31) and keeping the hits with the highest bit scores. 
192 Identification of putative methyltransferase genes To identify putative MTase genes in our reference strain, we downloaded the nucleotide sequences of all the entries 194 available for the Serratia genus in the REBASE database (Roberts et al., 2015) (http: //rebase.neb.com/rebase/rebase.html accessed on 2020-03-07) and performed a

196 local nucleotide-to-nucleotide blast search of those sequences against the assembled genome of our reference strain. In order to identify putative MTases missing from the

198 REBASE database, we also downloaded all the protein entries from the NCBI Identical Protein Groups (IPG) database using the search terms "DNA adenine methyltrans-

200 ferase" and restricting the search to the "bacteria" taxon (https://www.ncbi.nlm. nih.gov/ipg/ accessed on 2020-03-11). Those protein sequences were then matched

202 against our reference strain genome using a local protein-to-translated nucleotide blast search. The IPG database was accessed programmatically using the rentrez $\mathrm{R}$ package

204 (Winter, 2017).

\section{Calculation of tetramer composition bias along the genome}

In order to test if the main target sequence identified for adenine methylation $\left(5^{\prime}-\right.$ GATC-3') was under differential selection depending on the genomic context, we calculated the tetramer composition bias in two sets of chromosome segments: coding sequences (CDS) and promoter regions (defined as 200-bp-long regions immediately upstream of an operon-leading CDS). Sequences for CDS were taken from their $(+)$ strand, and sequences for promoters were taken from the strand corresponding to the (+) strand of the downstream CDS. For each of the 256 possible tetramers, we counted the total number of occurrences observed in those sets, $N_{\text {tet }}$, separately for CDS and for promoter sets. We compared those observed values with the expected number of occurrences based on two models: a zero-order model based on the frequencies of each nucleotide (A, T, G, C) in each segment and assuming that tetramers were generated from a random combination of those, and a Markov chain model taking into account the underlying biases that might exist in the frequencies of dimers and trimers compris- 
ing each tetramer in a given segment. In the zero-order model, the expected number of occurrences of a given tetramer in a sequence segment $i$ is (Pride et al., 2003):

$$
\mathrm{E}_{\mathrm{tet}, \mathrm{i}}^{\mathrm{zero}}=\left(p_{A}\right)^{a}\left(p_{T}\right)^{t}\left(p_{G}\right)^{g}\left(p_{C}\right)^{c} \times L
$$

where $p_{A}, p_{T}, p_{G}$ and $p_{C}$ are the observed frequencies of each nucleotide in the segment, $a, t, g$ and $c$ are the count of each nucleotide in the considered tetramer (between 0 and 4 ), and $L$ is the segment length. In the Markov chain approach, the expected number of occurrences of a given tetramer of composition $b_{1} b_{2} b_{3} b_{4}$ in a sequence segment $i$ is (Rocha et al., 1998; Pride et al., 2003):

$$
\mathrm{E}_{\mathrm{tet}, \mathrm{i}}^{\mathrm{MC}}=\frac{\mathrm{N}_{b_{1} b_{2} b_{3}} \times \mathrm{N}_{b_{2} b_{3} b_{4}}}{\mathrm{~N}_{b_{2} b_{3}}}
$$

where $\mathrm{N}_{b_{1} b_{2} b_{3}}, \mathrm{~N}_{b_{2} b_{3} b_{4}}$ and $\mathrm{N}_{b_{2} b_{3}}$ are the numbers of occurrences of the trimers $b_{1} b_{2} b_{3}$, $b_{2} b_{3} b_{4}$ and of the dimer $b_{2} b_{3}$ in segment $i$, respectively. For the CDS and promoter sets separately, we calculated the expected total number of occurrences as the sum of expected numbers for each segment $i$ : $\mathrm{E}_{\text {tet }}^{\text {zero }}=\Sigma_{i} \mathrm{E}_{\text {tet, }, \mathrm{i}}^{\mathrm{zero}}$ and $\mathrm{E}_{\text {tet }}^{\mathrm{MC}}=\Sigma_{i} \mathrm{E}_{\text {tet, } \mathrm{i}}^{\mathrm{MC}}$. Deviations in the usage of each tetramer from expectation were then calculated as:

$$
D_{\text {tet }}^{\text {zero }}=\frac{\mathrm{N}_{\text {tet }}-\mathrm{E}_{\text {tet }}^{\text {zero }}}{\mathrm{E}_{\text {tet }}^{\text {zero }}} \text { and } \quad D_{\mathrm{MC}}=\frac{\mathrm{N}_{\text {tet }}-\mathrm{E}_{\text {tet }}^{\mathrm{MC}}}{\mathrm{E}_{\text {tet }}^{\mathrm{MC}}}
$$

206 for the zero-order and the Markov chain models, respectively.

\section{Identification of partially methylated m6A loci in GATC motifs}

208 GATC motifs targetted by Dam are usually methylated on both strands, but hemimethylated or non-methylated locations can be inheritable features important for the

210 regulation of various cellular processes (Braaten et al., 1994; Casadesús and Low, 2006). To identify GATC loci which were not fully methylated in our dataset, we considered 212 the estimated fractions of methylated adenines at each GATC locus separately for the 
Epigenetics and adaptation

plus and the minus strands. In any given strain, loci for which no methylated fraction

214 was reported by the PacBio pipeline (event detection score $<20$ ) were assigned a value of 0 for that strain (i.e. non-methylated). Additionally, loci for which the modification

216 identity score was $<20$ in all strains were also considered not to be methylated as m6A. Assuming that the distribution of modified fractions on the plus and minus strands for

218 fully methylated loci would follow a truncated bivariate distribution centered around $(1,1)$ (i.e. both strands fully methylated), we defined the set of partially methylated

220 GATC loci of interest for downstream analyses as the loci which presented modified fractions on the plus or on the minus strand which deviated from the point of full

222 methylation at coordinates $(1,1)$ more than four times the average observed quadratic distance to $(1,1)$, in at least one strain (Supplementary Figure S4). We checked that low estimated values of methylated fractions were not a sequencing artifact due to low coverage of the corresponding GATC loci by examining the relationship between cover-

226 age bins and estimated methylated fraction (Supplementary Figure S3). We tested for association between genetic variants and methylated fractions of partially methylated

228 m6A epiloci using Wilcoxon rank-sum tests. For each genetic variant present in more than two sequenced genomes, we ran Wilcoxon tests against all partially methylated 230 m6A epiloci and applied a Benjamini-Hochberg false discovery rate (FDR) correction (Benjamini and Hochberg, 1995) on those tests p-values.

\section{Effect of evolutionary treatments on genetic and epigenetic}

\section{changes}

234 To test for an association between evolutionary treatments and genetic variants, we ran Fisher's exact tests on the contingency tables relating genotypes and evolutionary 236 treatments, for each genetic variant or linked variants (haplotypes) and for pooled variants (as defined in Figure 3a), with a Benjamini-Hochberg FDR correction to the 238 tests p-values.

To determine if some adenine methylation changes had been selected by the evo- 
lutionary treatments and were stable enough to persist after several generations in common garden conditions, we tested for association between evolutionary treatments and methylated fractions of partially methylated m6A with a methylated fraction range over the sequenced clones $>0.2$ using Kruskal-Wallis rank sum tests with Benjamini-

244 Hochberg FDR correction. In addition to those individual tests, and to investigate whether the genes related to m6A epiloci which tended to be associated with evolutionary treatments were consistently related to some biological processes, we performed a gene ontology enrichment analysis. Each partially methylated m6A epiloci was assigned a gene if it was contained in its CDS or, alternatively, if it was located less than 500bp upstream of it. A gene assigned to an m6A epiloci was assigned this epiloci's

250 Kruskal-Wallis test's uncorrected p-value. Genes assigned to more than one m6A epiloci were assigned their lowest p-values. The GO enrichment analysis was performed using

252 the topGO R package (Alexa and Rahnenfuhrer, 2020). The reference list of genes comprised all the genes assigned a Kruskal-Wallis test's p-value as described above, 254 and the subset of interest was the genes which had an uncorrected p-value $<0.05$. GO enrichment test was performed using Fisher's exact test and the "weight01" algorithm

256 (Alexa et al., 2006; Alexa and Rahnenfuhrer, 2020).

\section{Association between phenotypes and genetic and epigenetic}

\section{8 data}

We explored the association between genetic variants present in at least two sequenced

260 genomes and phenotypic traits using Wilcoxon rank sum tests with FDR correction. We investigated the association between methylated fraction of the partially methylated 262 m6A epiloci and phenotypic traits using Spearman's $\rho$. We analyzed only partially methylated epiloci with a methylated fraction range $>0.2$ and we assigned each epiloci

264 its overlapping gene or, alternatively, the closest downstream gene within 500bp (if any). 


\section{Results}

\section{Genome sequences and genetic variants}

268 We sequenced ten strains from the $31^{\circ} \mathrm{C}$ treatment, eight from the $38^{\circ} \mathrm{C}$ treatment and ten from the $24-38^{\circ} \mathrm{C}$ fluctuating treatment, as well as the original reference stock

270 strain used in the experimental evolution (Supplementary Figure S1). The reference strain chromosome was 5117300 bp long, with a GC content of 59.8\%. The genome

272 annotation by NCBI's PGAP predicted 4795 CDS, organized in 2686 operons according to Operon Mapper. 52 mutations were identified from the aligned genomes of the

274 reference and evolved strains, of which 35 were located inside coding regions and 32 were non-synonymous (Table 1 and Supplementary Figure S5). Some mutations always

276 occurred together in the sequenced strains: we use the term "haplotype" to refer to a set of linked mutations in our dataset (Table 1). Almost all identified haplotypes were

278 strain-specific mutations. However, a striking feature of the variant map is the presence of 11 genetic mutations associated into a single haplotype and for which the minor allele

280 is observed in 5 of the evolved strains from $38^{\circ} \mathrm{C}$ and in the reference genome, but in no other evolved strain (haplotype $a$ in Table 1). This suggests that the ancestor colony

282 used to initiate the replicated populations in the evolution experiment, and which was itself derived from the reference strain sequenced here, actually contained at least two

284 lineages which were preserved in some populations at $38^{\circ} \mathrm{C}$ but in no other evolutionary treatments. Even excluding variants from haplotype $a$, multiple parallel substitutions

286 were observed among the evolved strains (Figure S5). Some genes exhibited several independent mutations in different strains: two independent mutations occurred in a

288 deacetylase, three in a galactokinase and four in a glycosyltransferase (Table 1). 
bioRxiv preprint doi: https://doi.org/10.1101/822080; this version posted March 11, 2021. The copyright holder for this preprint (which was not certified by peer review) is the author/funder, who has granted bioRxiv a license to display the preprint in perpetuity. It is made available under aCC-BY 4.0 International license.

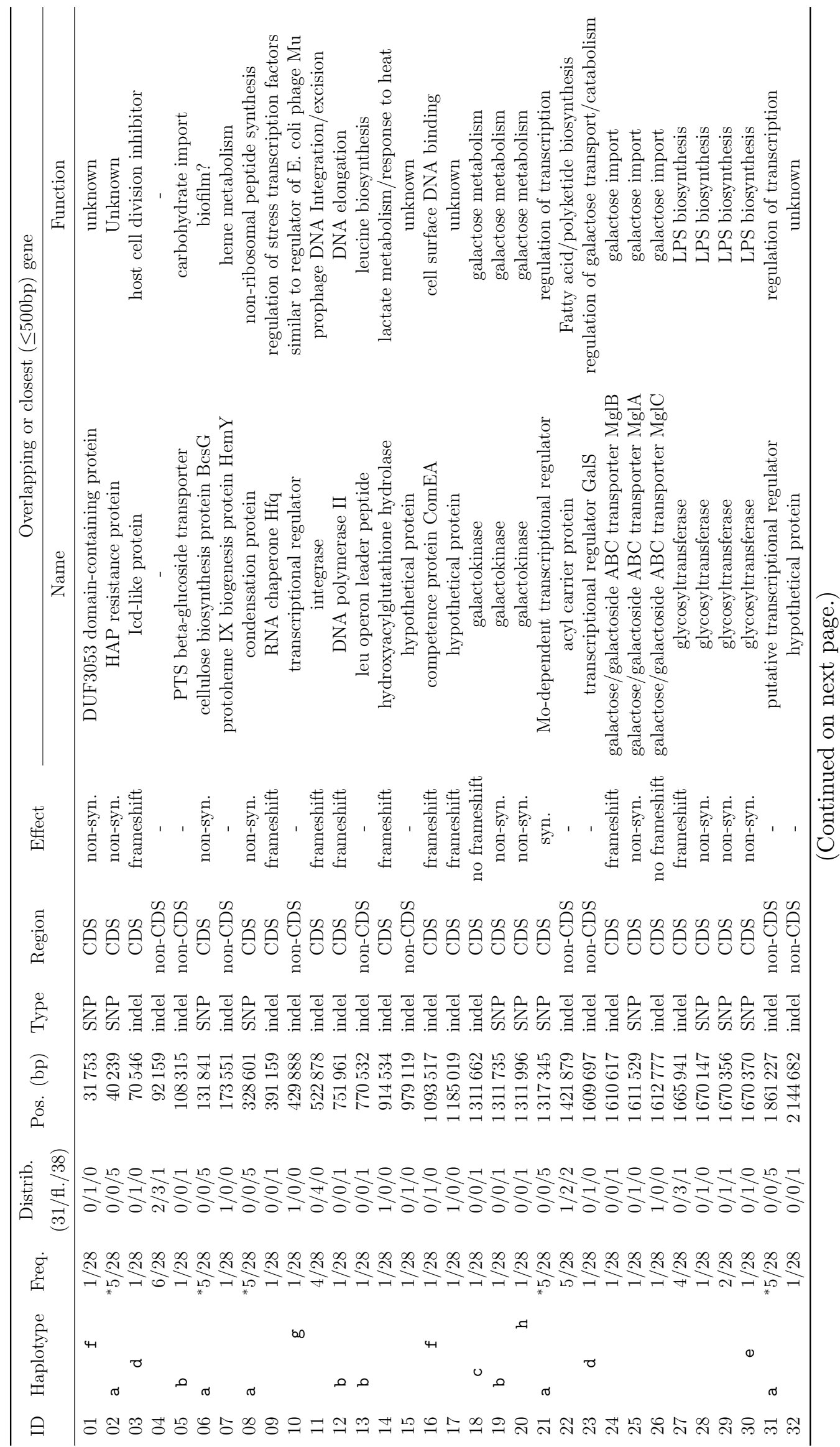


bioRxiv preprint doi: https://doi.org/10.1101/822080; this version posted March 11, 2021. The copyright holder for this preprint (which was

not certified by peer review) is the author/funder, who has granted bioRxiv a license to display the preprint in perpetuity. It is made available under aCC-BY 4.0 International license.

Epigenetics and adaptation

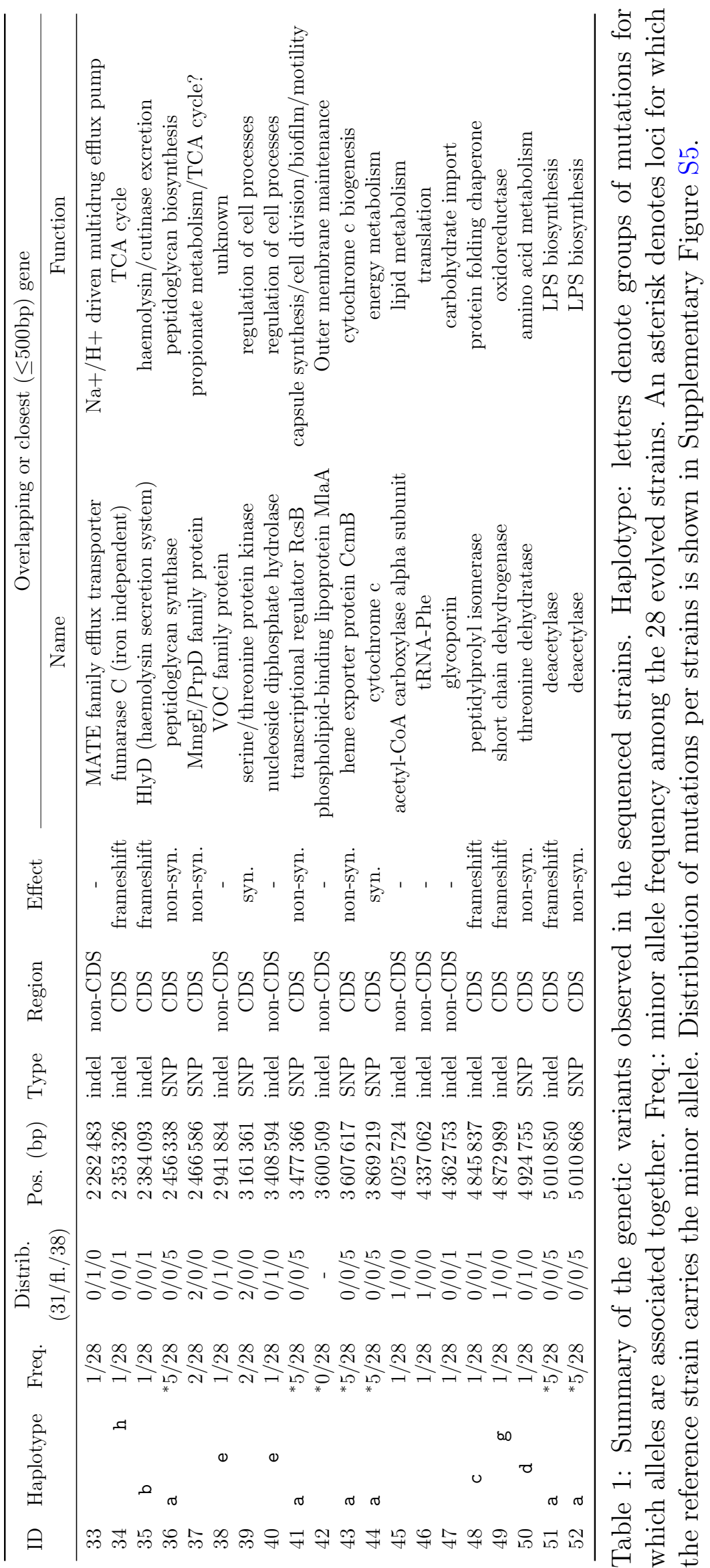




\section{Adenine methylation landscape in Serratia marcescens}

\section{Methylated bases and methylation motifs}

Out of 2057542 adenine bases present in the bacterial chromosome, $81434(4.0 \%)$

292 were detected as m6A (identification quality score $\geq 20$ in at least one of the evolved strains or in the reference strain). Most of those m6A were in GATC motifs: out of the 29481434 positions detected as m6A, 76228 (93.6\%) were in a GATC context. Since a total of 76300 adenines belong to a GATC context in the genome, this corresponds to a very high rate of adenine methylation in GATC motifs: $99.9 \%$ of GATC adenines are detected as m6A in at least one evolved strain or the reference strain and $99.7 \%$ were detected in all sequenced genomes. When detected as modified, m6A bases had an average methylated fraction of $70.3 \%$ (s.d. $28.3 \%$ ) outside GATC motifs and of $97.5 \%$

300 (s.d. $5.0 \%$ ) inside GATC motifs. We did not find any evidence of a problematic coverage effect on the ability to estimate low methylated fraction for m6A (Supplementary 302 Figure S3).

The PacBio pipeline identified two sets of motifs for adenine methylation (Table 2). One motif set for m6A was the GATC palindrome mentioned above and the other was the much rarer pair AAAGNNNNNNTCG / TTTCNNNNNNAGC. 306 For both sets, almost all genomic occurrences (> 99\%) were detected as modified.

\begin{tabular}{|c|c|c|c|}
\hline Motif & $\begin{array}{c}\text { Occurrences } \\
\text { on chromosome }\end{array}$ & $\begin{array}{c}\text { Detected } \\
\text { as methylated }\end{array}$ & $\begin{array}{l}\text { Methylated } \\
\text { fraction }\end{array}$ \\
\hline $5^{\prime}-\mathrm{GATC}-3^{\prime}$ & 38150 & \multirow{2}{*}{$99.9 \%$} & \multirow{2}{*}{$97.5 \%$} \\
\hline $3^{\prime}-\mathrm{CT} \underline{\mathrm{A}} \mathrm{G}-5^{\prime}$ & 38150 & & \\
\hline $5^{\prime}-\mathrm{AAAG}$ GNNNNNNTCG $-3^{\prime}$ & 882 & $100 \%$ & $93.8 \%$ \\
\hline $3^{\prime}-\mathrm{TTTCNNNNNNAGC-5^{ \prime }}$ & 882 & $100 \%$ & $96.3 \%$ \\
\hline
\end{tabular}

Table 2: Cognate sequence motifs for m6A modification. Methylated positions are underlined. Percentages of occurrences detected as methylated are reported as mean across the 29 sequenced samples; same for methylated fractions (calculated considering only methylated positions). 
Three candidate genes for adenine MTases were identified using REBASE, and no ad-

308 ditional candidates were identified using NCBI's IPG. One candidate was similar to M.Sma36365I, which is annotated as a type I MTase in REBASE and modifies the mo310 tif set AAGNNNNNGTTC / TTCNNNNNCAAG. It was located close to a restriction endonuclease in our reference strain genome, and is likely to be part of a restriction-

312 modification system. A second candidate was identified as a type II MTase targetting GATC and was located inside a predicted prophage on our reference strain chromo-

314 some. Finally, the third candidate was similar to the orphan MTase M.Sma13880DamP, which also targets GATC motifs.

\section{Genomic methylation profiles}

We investigated m6A methylation profiles around the boundary between the first CDS

318 of each predicted operon and the immediate upstream regions, which are likely to contain regulatory and promoter regions (Figure 1). From a base-composition perspective,

320 upstream regions have lower GC content that coding regions, which can be related to constraints on DNA curvature or double helix stability in promoter regions (Bohlin

322 et al., 2008) (Figure 1a). Average methylation of adenines into m6A bases was clearly lowered in upstream regions, in particular within $200 \mathrm{bp}$ of the translation start sites,

324 and reached background level again after a few tens of bp once in the operon coding regions (Figure 1b). This mostly mirrored the pattern observed for the proportion of 326 adenines located in GATC motifs (Figure 1c).

\section{GATC usage bias in Serratia marcescens genome}

328 Oligonucleotide usage bias in prokaryotic genomes exists as a result of evolutionary constraints, such as codon usage bias and palindrome avoidance (Rocha et al., 1998).

330 To investigate if any such evolutionary constraint dictated the distribution of the main S. marcescens adenine methyltransferase cognate motif in promoter regions, we

332 searched for evidence of differential usage bias of the 5'-GATC-3' tetramer between 
(a) GC content

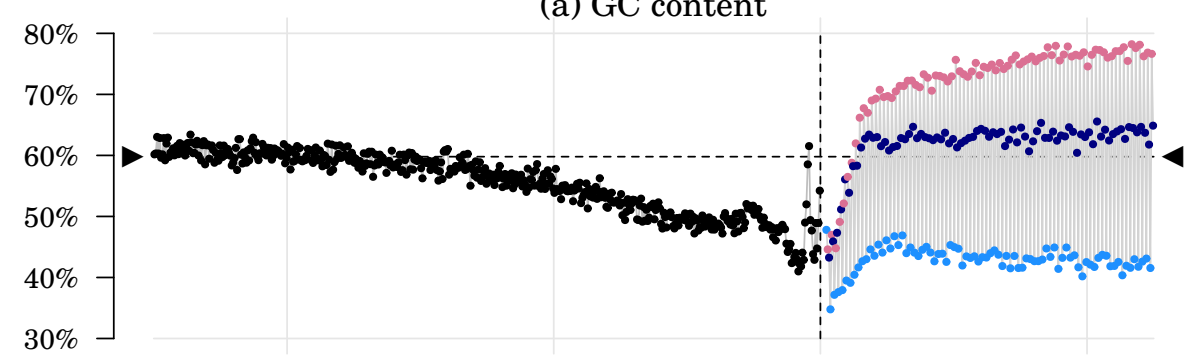

(b) Average methylated fraction $(\mathrm{m} 6 \mathrm{~A})$ of adenines

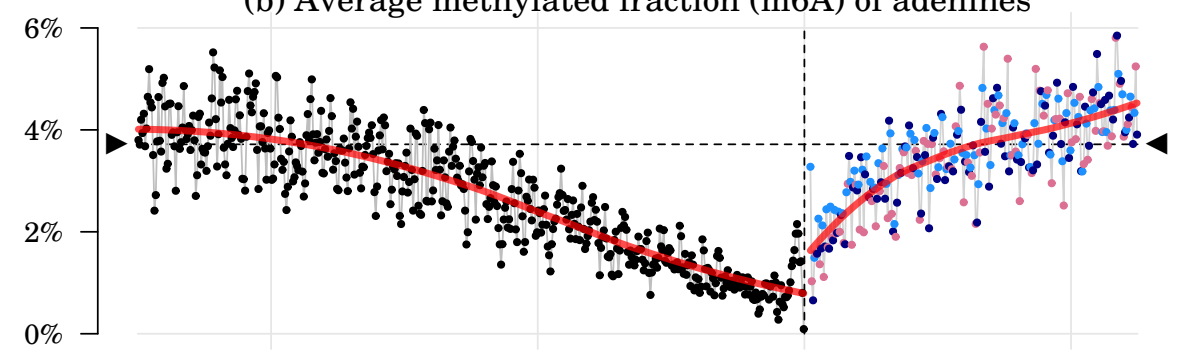

(c) Proportion of adenines located in a GATC motif

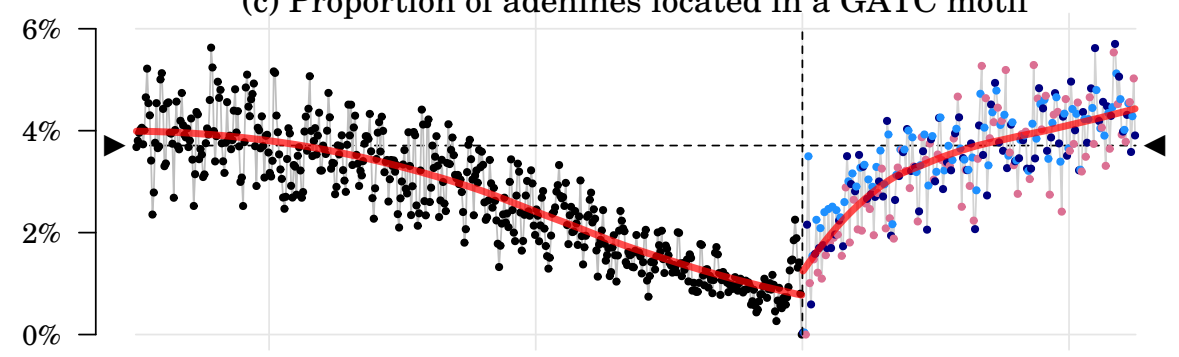

(d) Proportion of partially methylated m6A in GATC

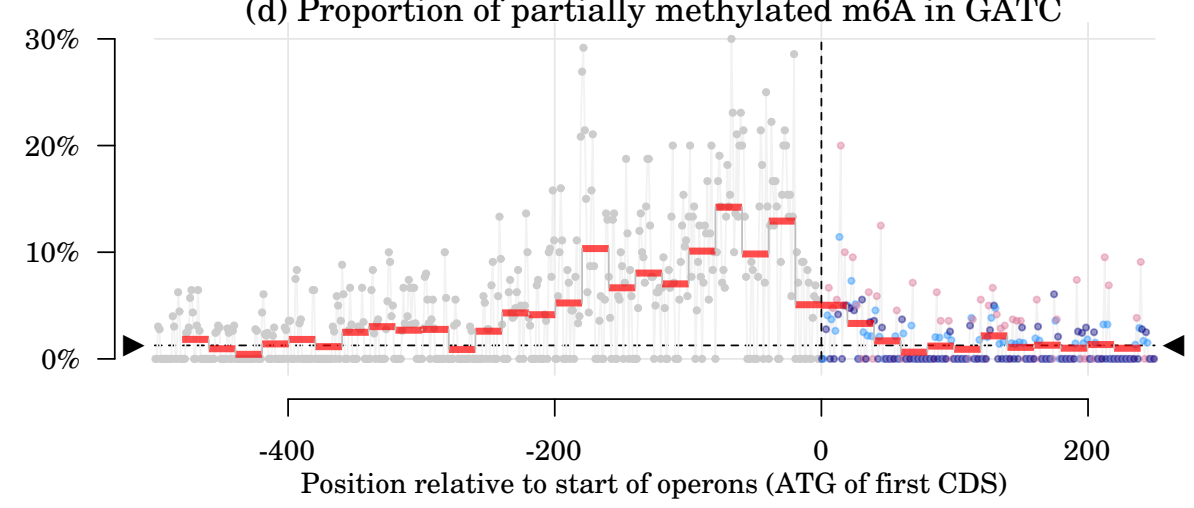

Figure 1: Profiles of nucleotide composition and adenine methylation around the start positions of operon-leading CDS. Red lines: LOESS regression (in (b) and (c), span $=0.75$ ) and binned values (in $(\mathrm{d})$, width $=20 \mathrm{bp}$ ). Data points are averaged over each position relative to the leading CDS initiation codon, based on the 2686 operons predicted in the reference genome. Horizontal dashed lines and black triangles show genome-wide average values. Values for the three first bases on the coding sequences (usually ATG) are dropped from the plot to keep the y-scale reasonably narrow. 
(a) Zero-order model
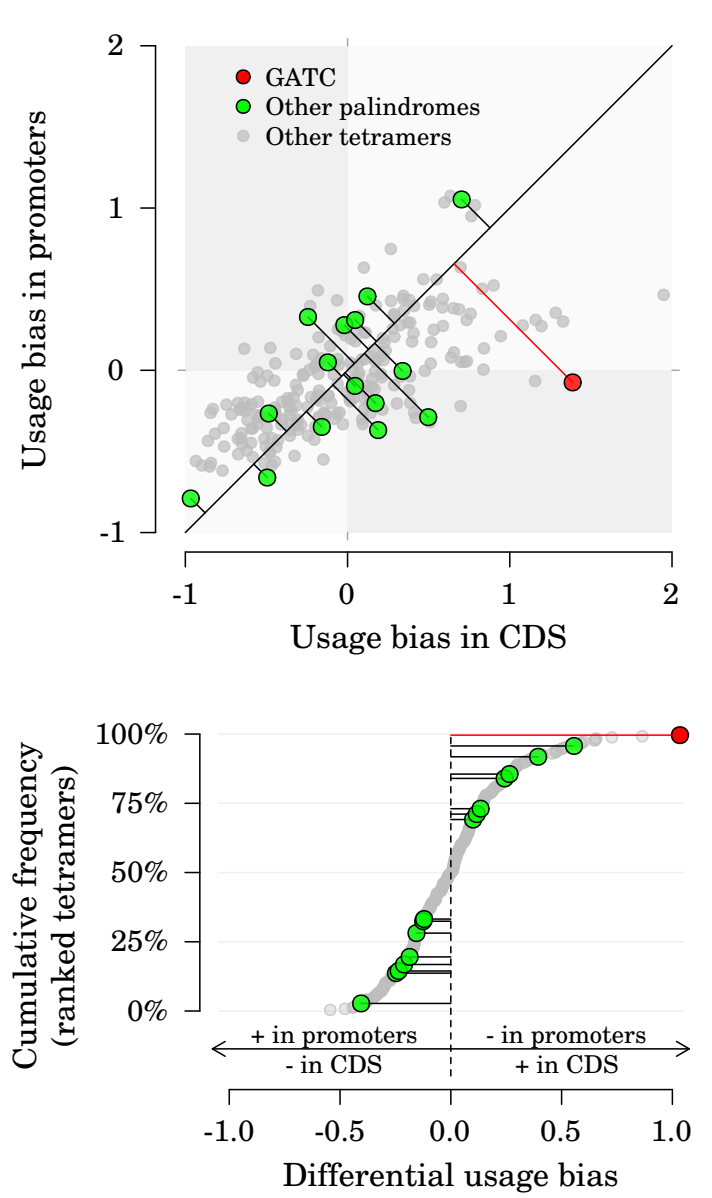

(b) Markov chain model
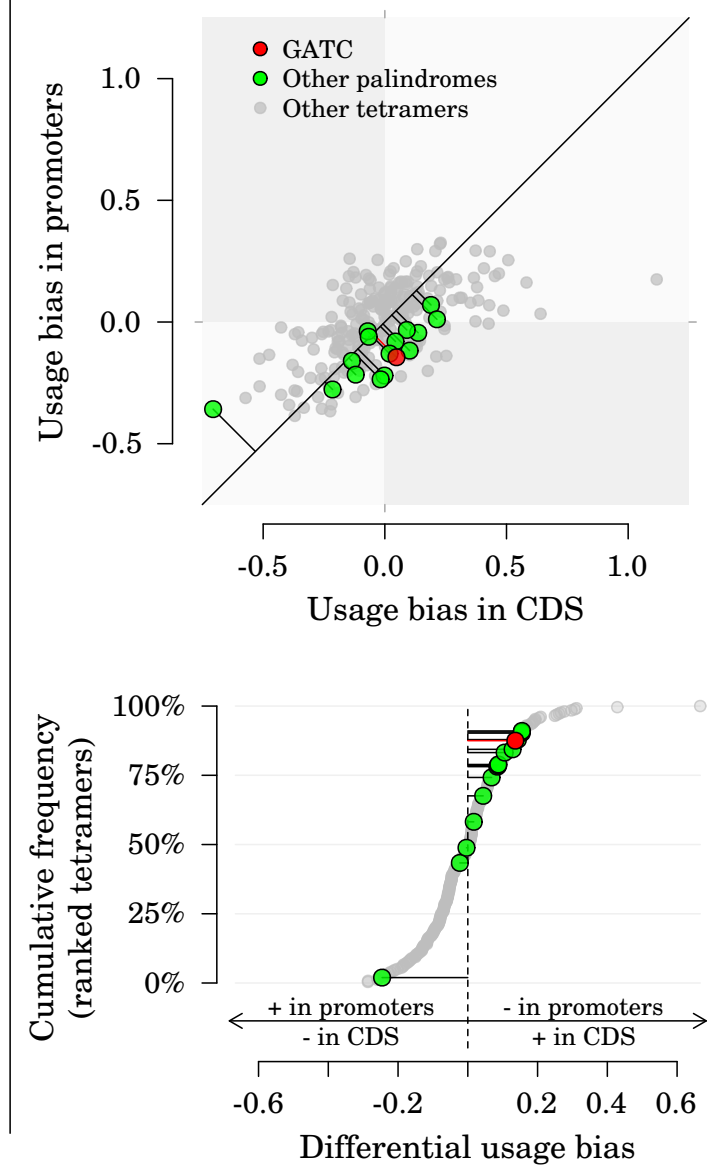

Figure 2: Tetramer usage bias in coding sequences (CDS) and promoters. (a) bias calculation based on observed single-nucleotide frequencies (zero-order approach). (b) bias calculation taking into account the observed frequencies of dimers and trimers (Markov chain approach). In the upper panels, the distance between a data point and its projection on the identity line measures how imbalanced the usage biases between CDS and promoters are (i.e. the differential usage bias). In the lower panels, those differential usage biases are sorted across all tetramers. 
coding sequences (CDS) and promoters, defined here as 200-bp long regions upstream

334 of operon-leading CDS. In practice, we compared the usage bias of GATC with the usage bias of all other nucleotide tetramers (Figure 2). The usage bias for a tetramer

336 in a given genomic region is positive if the tetramer is more abundant than expected by chance, and negative if it is rarer. Overall, the range of tetramer usage bias in CDS and

338 promoters was larger when measured from a zero-order approach (deviation ranging from -0.97 to +1.95$)$ than from a Markov chain approach $(-0.71$ to +1.12$)$. The cor-

340 relation between values obtained from the two approaches was moderate (Spearman's $\rho=0.20$ ), indicating that tetramer usage biases are strongly related to biases in dimers

342 and trimers usage which are taken into account by the Markov chain approach but not by the zero-order approach. Most of the variation in tetramer usage bias was posi-

344 tively correlated between CDS and promoters (Spearman's $\rho=0.58$ for Markov chain estimates), but some tetramers exhibited large differences between their in-CDS and

346 in-promoter usage biases (Figure 2). Remarkably, 5'-GATC-3' showed one of the largest distortions in usage bias between CDS and promoter regions among all tetramers, in

348 both approaches. The $5^{\prime}$-GATC-3' tetramer was rarer in promoters and more frequent in CDS than expected by chance, even when taking into account underlying biases in 350 dimer and trimer usage (Figure 2).

\section{Identification of partially methylated m6A epiloci}

352 Non-methylated and hemimethylated GATC loci are usually rare in the genome of bacteria species possessing an adenine MTase targetting this motif. Such GATC loci

354 can be involved in the regulation of DNA replication and of DNA-protein interactions and their methylation status can potentially be transmitted to the next generation

356 (Braaten et al., 1994; Casadesús and Low, 2006). Here, most adenines in GATC motifs were observed close to full methylation but we identified 892 partially methylated 358 adenines in GATC motifs, i.e. $1.2 \%$ of all adenines in GATC motifs. They were located in 451 distinct GATC palindromes. We considered those partially methylated m6A as 
360 the m6A epiloci of interest and used them for downstream analyses of association with genetic and phenotypic data. Taking into account the genomic distribution of all

362 GATC motifs, partially methylated m6A were more frequent than expected in promoter regions $\left(\chi^{2}=1417.3, d f=1, p<0.001\right)$ and rarer than expected in operons $\left(\chi^{2}=\right.$

364 2908.5, $d f=1, p<0.001$ ), as is visible in Figure 1d. Finally, very little evidence of association between genetics and epigenetics was found in this experiment: based on

366 FDR-corrected Wilcoxon rank-sum tests, associations with p-values $\leq 0.05$ were only observed between haplotype $a$ and five epiloci.

\section{Effect of evolutionary treatments on genetic and epigenetic}

\section{changes}

370 Before FDR correction, only haplotype $a(p<0.001)$, pooled variants for glycosyltransferase $(p=0.007)$ and for galactokinase $(p=0.017)$ and variant $11(p=0.024)$

372 were tentatively associated with evolutionary treatments (p-values $<0.05)$. After FDR correction, only haplotype $a(p=0.018)$ remained significantly associated with evolutionary treatments, being only observed in evolved strains from the $38^{\circ} \mathrm{C}$ treatment and in the reference strain (Table 1 and Supplementary Figure S5).

Concerning the association between evolutionary treatments and partially methylated m6A epiloci, no association was significant at the $p<0.05$ level after FDR correction. We examined if some gene ontology terms were significantly enriched in the genes which were the closest to the m6A epiloci which were tentatively associated with evolutionary treatments (uncorrected p-value for association $<0.05$ ). Using Fisher's exact test and the "weight01" algorithm (Alexa et al., 2006; Alexa and Rahnenfuhrer, 2020), five biological process (BP) categories were enriched in this set of genes (topGO's $p<0.05$ ): "cellular response to stress", "lipopolysaccharide biosyn-

384 thetic process", "negative regulation of cellular process", "L-amino acid transport" and "cellular component biogenesis". 


\section{Association between phenotypes and genotypes}

We explored the association between genetic variants present in at least two sequenced genomes and phenotypic traits using Wilcoxon rank sum tests with FDR correction (Figure 3a). The only genetic variants associated with phenotypic traits at the level $390 \quad p<0.05$ were those comprising haplotype $a$, which were associated with growth rate and yield in the presence of a virus and yield at $24^{\circ} \mathrm{C}$. Those trait values decreased

392 in the presence of the minor allele (Figure 3b). Pooled variants for a galactokinase and a glycosyltransferase were tentatively associated with some traits $(p<0.1)$ : for

394 example, the minor alleles related to the glycosyltransferase were potentially associated with higher growth rate at $31^{\circ} \mathrm{C}$, in the presence of DTT or in the presence of a virus.

396 Association between phenotypes and partially methylated epiloci

398 We examined the association between methylated fraction of the partially methylated m6A epiloci and phenotypic traits using Spearman's $\rho$ and assigning the m6A epiloci

400 to the closest genes (Figure 4). Forty genes were related to a partially methylated m6A epiloci tentatively associated with at least one trait, using an uncorrected p-value threshold of 0.005 for Spearman's correlation. We did not apply FDR correction in this analysis, as the large number of tests run $(10$ traits $\times 892$ partially methylated epiloci $=$ 4048920 tests) and the relatively small sample size of each test (28 evolved strains) resulted in all FDR-adjusted p-values to be $>0.25$, even when the original uncorrected p-values

406 were $<10^{-4}$. Gene ontology enrichment tests performed with topGO on a trait-bytrait basis revealed only very broad functional categories for genes associated with a

408 given trait, such as metabolism, molecule transport, regulation of cellular processes, cell communication and response to chemical stimulus (Supplementary Table S1). Based

410 on those functions, we performed a literature search for each of those forty genes to determine which had ever been found related to metabolism, nutrient uptake, cell 
bioRxiv preprint doi: https://doi.org/10.1101/822080; this version posted March 11,2021. The copyright holder for this preprint (which was not certified by peer review) is the author/funder, who has granted bioRxiv a license to display the preprint in perpetuity. It is made available under aCC-BY 4.0 International license.
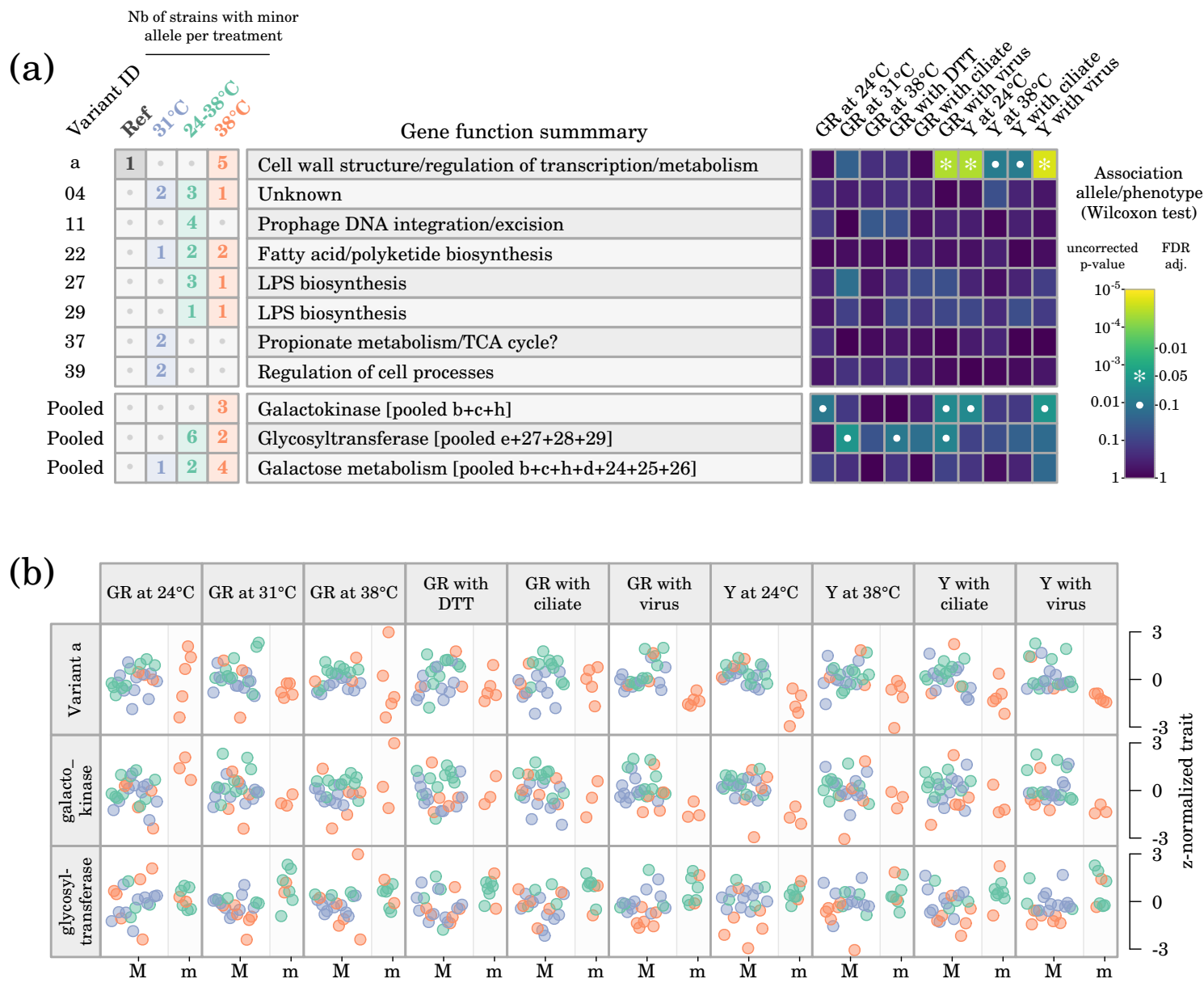

Figure 3: Association between genetic variants observed in at least two sequenced genomes and phenotypes. (a) Distributions of variants across evolutionary treatments and association between alleles and phenotypic traits (GR, growth rate; Y, yield). "Pooled" variants are variants affecting the same enzyme or function. (b) Detailed illustration of the association between major $(\mathrm{M})$ and minor $(\mathrm{m})$ alleles and phenotypes for variant $a$ and for the "pooled" variants related to the galactokinase and to the glycosyltransferase. Data point colors correspond to the evolutionary treatment of each strain. 
bioRxiv preprint doi: https://doi.org/10.1101/822080; this version posted March 11, 2021. The copyright holder for this preprint (which was not certified by peer review) is the author/funder, who has granted bioRxiv a license to display the preprint in perpetuity. It is made available under aCC-BY 4.0 International license.
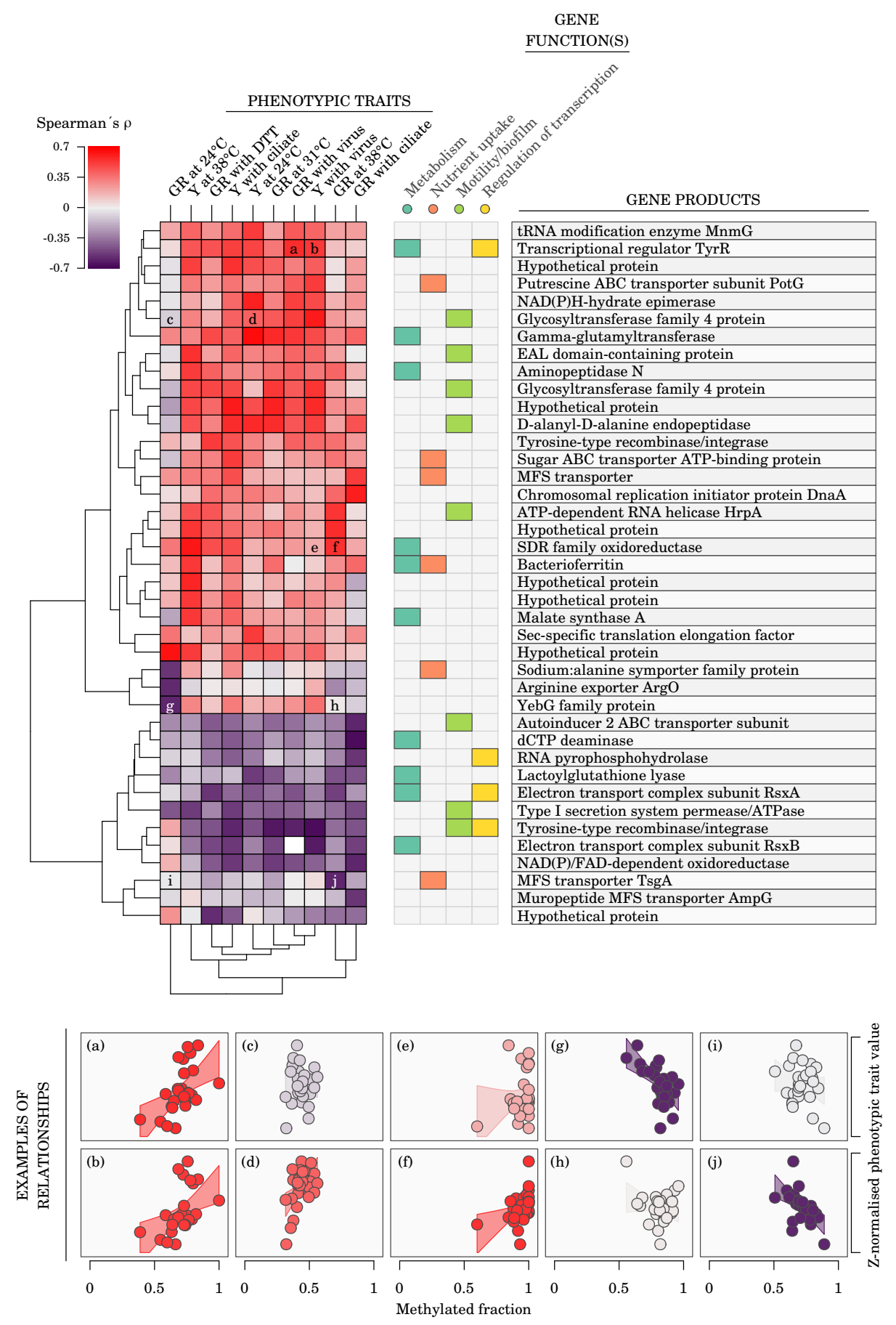

Figure 4: Association between adenine methylation and phenotypes. The heatmap shows Spearman's correlation between methylated fractions of partially methylated m6A epiloci (rows) and phenotypes (columns; GR, growth rate; Y, yield) for partially methylated $\mathrm{m} 6 \mathrm{~A}$ epiloci exhibiting a methylation fraction range $\geq 0.2$ across sequenced samples and an uncorrected p-value $\leq 0.005$ for Spearman's $\rho$ with at least one trait. Overlapping or closest $(\leq 500 \mathrm{bp})$ downstream genes are assigned to each epiloci. Gene functions are based on manual literature search for each gene product. Examples of relationships between m6A methylated fractions and phenotypes are given for the heatmap cells annotated with a letter. 
412 motility and biofilm formation, or regulation of transcription, and found that most of those genes were related to at least one such category (Figure 4).

\section{Discussion}

We have shown that substantial variation in adenine methylation existed in Serratia 416 marcescens strains after experimental evolution followed by common garden conditions, and that GATC motifs and partially methylated m6A epiloci were not randomly

418 distributed along the genome. Sequenced strains were genetically clonal but they exhibited polymorphism in a small fraction of their m6A epiloci. In addition to de

420 novo mutations, genetic variants were dominated by 11 linked loci (haplotype $a$ ) which were only observed in strains evolving at $38^{\circ} \mathrm{C}$ and suggested the existence of some degree of genetic polymorphism in the ancestor strain and differential selection between temperature treatments during the experiment. No clear effect of evolutionary 424 treatments on specific m6A epiloci was found, suggesting that parallel environmentallyinduced or environmentally-selected changes on particular epiloci were rare or labile

426 in our experiment. Both genetic and epigenetic data were associated with some phenotypic traits to some extent. Surprisingly, the involved genes were not related to

428 temperature response in particular but rather related to metabolism, nutrient uptake, motility/biofilm/adhesiveness and cell wall structure.

\section{Methylation landscape in S. marcescens}

E. coli and several other Gammaproteobacteria possess a Dam enzyme responible for 432 m6A methylation of GATC motifs (Hattman et al., 1978; Casadesús, 2016), and GATC adenine methylation in those species is involved in important functions such as protec-

434 tion against foreign DNA, timing of DNA replication and regulation of gene expression (Casadesús, 2016). S. marcescens is known to also harbour a Dam enzyme targetting

436 GATC motifs (Ostendorf et al., 1999). The detailed S. marcescens adenine methylation 
bioRxiv preprint doi: https://doi.org/10.1101/822080; this version posted March 11, 2021. The copyright holder for this preprint (which was

not certified by peer review) is the author/funder, who has granted bioRxiv a license to display the preprint in perpetuity. It is made available under aCC-BY 4.0 International license.

Epigenetics and adaptation

data we collected in our experiment indeed allowed us to identify two cognate motifs in this species, including GATC. Putative adenine methyltransferases were identified in the genome, two of which could be orphan MTases responsible for GATC methylation.

440 About $4 \%$ of observed m6A positions were outside the identified cognate motifs, which suggests either off-target methylation by specific MTases (Murray et al., 2012), the existence of an unspecific DNA adenine MTase (Murray et al., 2018), or that some of those detected methylation events could possibly be false positives (McIntyre et al., 2019).

Dam activity in $S$. marcescens has been shown to play a role in mutation avoidance by keeping track of the reference strand during post-replication mismatch repair (Ostendorf et al., 1999). Here, several lines of evidence based on the genomic distrimethylation in $S$. marcescens is likely to be involved in other cell functions than solely recognition of foreign DNA or help in mismatch repair, such as gene expression regulation. Firstly, average adenine methylation was lower in regulatory and promoter 452 regions than in the rest of the genome (Figure 1b), which was primarily due to the lower frequency of GATC motifs in those regions (Figure 1c). Secondly, this unbalanced distribution of GATC motifs was not fully accounted for by the underlying distributions of constituting di- and trinucleotides: the Markov chain model showed that GATC were rarer than expected in promoters but more frequent in CDS, suggesting that evolutionary constraints on the GATC motif differ between those genomic

458 regions (Figure 2). Finally, partially methylated sites were not randomly distributed among the GATC sites but were more frequent in promoters and rarer in coding re460 gions (Figure 1d). Those observations are consistent with previous results in E. coli, where GATC motifs are also more frequent in coding rather than non-coding regions 462 (Barras and Marinus, 1988) and GATC located in 5' upstream regions of CDS are more frequently under-methylated (Tavazoie and Church, 1998). In E. coli, GATC methy464 lation in gene regulatory regions is responsible for phase variation (Blyn et al., 1990) 
(but not all methylation in regulatory regions lead to regulation of gene expression -

466 see for example van der Woude et al. (1998)). Oshima et al. (2002) suggested that GATC in upstream regions could modulate gene expression by interacting with some 468 regulatory proteins, while Riva et al. (2004) argued that the regulation of expression was due to clusters of GATC situated inside the coding regions and which would affect

470 DNA stability and thus expression based on their methylation status.

Finally, while each sequenced strain in this experiment appeared genetically clonal,

472 it is important to note that the methylated fractions observed within a given strain show that most of the partially methylated m6A epiloci were heterogeneously methylated

474 in the culture: about $55 \%$ of the methylated fraction values for those epiloci were between 0.2 and 0.8 , showing that cells in a single culture are differently methylated

476 at those epiloci. Methylated fraction must thus be considered a culture-level property, rather than a cell-level characteristic, in the same way that bacterial phenotypic traits 478 such as growth rate and yield are measured for a culture, not for an individual cell.

\section{Effect of evolutionary treatments on adenine methylation}

480 The origin of epigenetic variation and its stability are two fundamental evolutionary questions. Changes in methylation at a genomic locus can be either genetically determined, spontaneous, or environmentally induced. In eukaryotic systems, for example, most methylation changes observed in natural plant populations generally seem

484 to be under genetic control (Dubin et al., 2015; Hagmann et al., 2015) but only a small proportion of methylation changes were under genetic control during experimen-

486 tal evolution of Chlamydomonas algae (Kronholm et al., 2017). In eukaryotes again, both spontaneous epigenetic changes (van der Graaf et al., 2015) or environmentally 488 induced changes (Jiang et al., 2014; Wibowo et al., 2016) have also been observed. In prokaryotes, even though the mechanisms involved in methylation processes are 490 markedly different from the eukaryotic ones, those three types of methylation changes are also possible: genetically determined changes (e.g. mutations affecting the MTase 
Epigenetics and adaptation Reich (2008)), spontaneous (stochastic competition between MTase and DNA binding protein heritable via self-regulating loops), and environmentally induced (when other DNA binding proteins influencing MTase access to DNA are responding to environ496 ment, like in the case of the pap operon or the agn 43 gene in E. coli; Wallecha et al. (2002); Casadesús and Low (2013)). Importantly, the stability of methylation states in prokaryotes can vary from a regular resetting during DNA replication to bistable epigenetic switches underpinning phase variation. For a given epigenetic switch, OFF-to-ON

500 and ON-to-OFF rates can differ, allowing for some relative stability after a switching event (Kaminska and van der Woude, 2010; Olivenza et al., 2019). Epigenetic changes

502 in bacteria can thus be involved in both short-term, partially heritable phenotypic plasticity and in long-term response, possibly allowing for later genetic assimilation.

504 Given our experimental design, our conclusions below apply only to epigenetic changes that can remain stable for several generations rather than to the more labile ones.

We did not find any strong evidence to support a genetic control of adenine methylation in our experiment, as only five m6A epiloci were found associated with haplotype $a$. While the statistical power to detect association from our data is limited since there is no segregation among the bacterial clones, extensive genetic control would require 510 assuming that each genetic mutation controls multiple different epiloci in order for genetic mutations to explain the observed epigenetic variation. Furthermore, the limited

512 association observed between m6A epiloci and haplotype $a$ could be be due to the shared history of those epiloci with haplotype $a$ prior to the initiation of the evolution

514 experiment (assuming that haplotype $a$ was part of some standing genetic variation in the ancestor culture at the initiation of the experimental populations).

516 Any consistent methylation pattern associated with multiple clones from a given evolutionary treatment can in principle be due to methylation states induced by a 518 common environment or explained by spontaneous changes that were environmentally selected in multiple populations, thus reflecting parallel evolution. It is also possible 
Epigenetics and adaptation

520 that some epiloci have extremely high forward- and back-mutations rates, so that some polymorphism is always present, or that the optimal fitness of a given culture

522 is composed of a mix of subpopulations heterogeneously methylated. We did not observe any partially methylated m6A epiloci whose methylated fraction would be

524 significantly associated with evolutionary treatments, which suggest that no parallel epigenetic changes were either induced nor selected by the evolutionary treatments, or that changes would be too labile to persist over a few generations in common garden conditions. Most of the observed epigenetic variation is thus likely to be spontaneous,

528 stochastic fluctuations, for which our experimental design does not allow to determine if they affect the phenotype or are neutral. Highly labile epigenetic fluctuations could

530 possibly reflect some sort of epigenetic bet-hedging mechanism (Veening et al., 2008). Our observations do not preclude, however, that environmental conditions could exert

532 selective pressure on stochastic epigenetic variation at different epiloci that would affect a common biological process. Indeed, the results of the gene ontology enrichment

534 analysis of the genes located by the m6A epiloci most associated with evolutionary treatments suggest that environmental pressure could act as a sieve selecting distinct

536 epigenetic changes related to common, important biological functions.

\section{Distribution of genetic variants among evolutionary treatments}

538 Most of the genetic variants observed in our experiment were present in single strains and we cannot determine if those variants provide an advantage in a specific evolution-

540 ary treatment or in the laboratory conditions in general. The only variant that was statistically associated with a particular treatment was haplotype $a$, which comprised

54211 linked loci and was observed only in evolved strains from the $38^{\circ} \mathrm{C}$ treatment. Haplotype $a$ was also found in the reference strain from which the ancestor used for the

544 evolution experiment was derived. The probability of 11 mutations arising independently and in succession in several strains in our dataset is low given the duration of 546 the evolution experiment. It is thus likely that the ancestor culture used to initiate 
Epigenetics and adaptation

all the populations of the experiment exhibited some genetic diversity in relation with haplotype $a$, possibly due to cell aggregation occurring during the preparation of the ancestor colony. No sign of this diversity is observed in the sequenced strains evolved

550 at $31^{\circ} \mathrm{C}$ and $24-38^{\circ} \mathrm{C}$, indicating that haplotype $a$ was driven to low frequencies or extinction in $31^{\circ} \mathrm{C}$ and $24-38^{\circ} \mathrm{C}$ conditions. This indicates that evolving at lower av-

552 erage temperature might impose stronger selective constraints on the genetic variants in our experimental setup while higher temperature allowed for more diverse genetic

554 trajectories.

Interestingly, we observed mutations occurring independently at different positions

556 within several genes and being selected in parallel. This happened independently of haplotype $a$ for a galactokinase and for a glycosyltransferase. Given the large effective 558 population size in our experiment $\left(N_{e}=2.6 \times 10^{6}\right.$, see Methods), genetic drift cannot explain the fixation of multiple parallel mutations in independent populations, sug-

560 gesting instead that selection favoured a modified function for those particular genes. Remarkably, those two genes and the deacetylase gene (with two linked mutations

562 belonging to haplotype $a$ ) are all involved in the biosynthesis of lipopolysaccharide. Mutations in those three genes were observed in the $24-38^{\circ} \mathrm{C}$ and $38^{\circ} \mathrm{C}$ treatments, 564 but not in the $31^{\circ} \mathrm{C}$ treatment.

\section{Effect of genetic and epigenetic variation on phenotypes}

566 Our main objective was to determine the potential contributions of genetics and epigenetics to adaptation in rapidly changing environments. In the original evolution

568 experiment during which the evolved strains were generated, 12 colonies were isolated from each replicate population, thus providing good statistical power to detect an effect

570 of evolutionary treatment on phenotypic traits and enabling to show that strains from the fluctuating $24-38^{\circ} \mathrm{C}$ treatment outperformed strains that evolved at constant $31^{\circ} \mathrm{C}$

572 (Ketola et al., 2013). In the subset of strains we sequenced here, phenotypic variability results in overlapping phenotype ranges across treatments (Supplementary Figure 
Epigenetics and adaptation

574 S2). Given this overlap, trying to link genetic and epigenetic data directly to phenotypic trait values rather than to evolutionary treatments might give insight into how

576 genetic variants and partially methylated m6A epiloci can influence phenotype. Note that given our experimental design, where evolved clones were isolated and cultured

578 in common garden conditions before phenotypic measurements and DNA extraction, short-lived epigenetic changes involved in rapid phenotypic plasticity would be lost and only more persistent changes, stable over several generations and more amenable to playing a role in evolution, would be carried over from the evolution experiment.

Evidence supporting a potential effect on phenotypes was found both for genetic variants and for partially methylated m6A epiloci. Given that most genetic variants were present in only one strain, the ability to detect statistically significant associations was limited, but haplotype $a$ was associated with some reduced performance in the strains evolved at $38^{\circ} \mathrm{C}$ and independent genetic variants associated with galactokinase and glycosyltransferase were tentatively associated with phenotypic changes.

588 From a general biological perspective, those genes and the genes affected by haplotype $a$ are somehow related to cell wall structure, metabolism and regulation of transcription,

590 which are all crucial cell functions likely to be impacted when environmental conditions change, but not to thermal stress in particular, and were associated both with

592 temperature-related traits and with performances in novel environments (exposure to DTT, ciliate or virus). Similarly, partially methylated m6A epiloci which were found 594 to be associated with phenotypes were related to genes involved in important, broad functional categories (metabolism, nutrient uptake, motility and biofilm formation).

596 Metabolism and nutrient uptake are both likely to be crucial in determining growth rate and yield, especially after evolving in a nutrient-limiting medium such as SPL 1\%.

\section{Conclusion}

We have shown that substantial epigenetic variation existed in adenine methylation 600 in Serratia marcescens, both across and within cultures of evolved strains. The dis- 
Epigenetics and adaptation

tribution of methylated fractions and of the main adenine MTase cognate motif along

602 the genome pointed to a probable connection between adenine methylation and gene expression regulation, as is the case in other Gammaproteobacteria. No clear evidence

604 of a genetic control of epigenetic variation, nor of stable environmentally-induced or environmentally-selected epigenetic changes were found in our experiment. However,

606 this result does not rule out the existence of labile, short-term epigenetic responses in particular in fluctuationg environmental conditions, which could be explored with

608 more massive methylome sequencing of evolved strains grown in their treatment conditions and challenged in new conditions. Genetic variants from unexpected pre-existing

610 standing genetic variation at the beginning of the evolution experiment seemed to be responsible for the majority of divergent phenotypic adaptation between the $38^{\circ} \mathrm{C}$

612 treatment and the others, but indications of both genetic and epigenetic effects on some of the phenotypic traits observed in our experiment were found.

614 Acknowledgements. We acknowledge the Academy of Finland (Project 278751) and the Centre of Excellence in Biological Interactions for funding and facilities, and

616 CSC-IT center for Science for computational resources.

Authors contributions. TK and IK conceptualized the study. Experimental design 618 for PacBio sequencing was done by TK and MB. DNA extraction for PacBio sequencing was done by RA. MB, IK and TK analyzed the data and wrote the original draft with 620 later review by all co-authors.

Conflict of interest. The authors declare no competing financial interests.

622 Data availability. PacBio sequencing data (HDF5 files) were submitted to the European Nucleotide Archive's Sequence Read Archive (ENA-SRA) (https://www . ebi .ac .

624 uk/ena, project PRJEB40306) and assembled genomes to NCBI's GenBank (biosamples SAMEA7301478 to SAMEA7301506). Genetic, epigenetic and phenotypic datasets 
bioRxiv preprint doi: https://doi.org/10.1101/822080; this version posted March 11, 2021. The copyright holder for this preprint (which was

not certified by peer review) is the author/funder, who has granted bioRxiv a license to display the preprint in perpetuity. It is made available under aCC-BY 4.0 International license.

Epigenetics and adaptation

used for analysis will be submitted to the Dryad repository (https ://datadryad.org).

\section{References}

Adam M, Murali B, Glenn NO, Potter SS. 2008. Epigenetic inheritance based evolution of antibiotic resistance in bacteria. BMC Evolutionary Biology. 8(1):52.

Alexa A Rahnenfuhrer J. topGO: Enrichment Analysis for Gene Ontology, 2020. R package version 2.42.0.

632 Alexa A, Rahnenführer J, Lengauer T. 2006. Improved scoring of functional groups from gene expression data by decorrelating GO graph structure. Bioinformatics. 22 (13):1600-1607.

Angiuoli SV Salzberg SL. 2011. Mugsy: fast multiple alignment of closely related whole genomes. Bioinformatics. 27(3):334-342.

Atack JM, Srikhanta YN, Fox KL, Jurcisek JA, Brockman KL, Clark TA, Boitano M, Power PM, Jen FEC, McEwan AG, Grimmond SM, Smith AL, Barenkamp SJ, Korlach J, Bakaletz LO, Jennings MP. 2015. A biphasic epigenetic switch controls immunoevasion, virulence and niche adaptation in non-typeable Haemophilus influenzae. Nat Commun. 6:7828.

Barras F Marinus MG. 1988. Arrangement of Dam methylation sites (GATC) in the Escherichia coli chromosome. Nucleic Acids Research. 16(20):9821-9838.

Benjamini Y Hochberg Y. 1995. Controlling the False Discovery Rate: A Practical and Powerful Approach to Multiple Testing. Journal of the Royal Statistical Society. Series B (Methodological). 57(1):289-300.

Blow MJ, Clark TA, Daum CG, Deutschbauer AM, Fomenkov A, Fries R, Froula J, Kang DD, Malmstrom RR, Morgan RD, Posfai J, Singh K, Visel A, Wetmore K, 
bioRxiv preprint doi: https://doi.org/10.1101/822080; this version posted March 11, 2021. The copyright holder for this preprint (which was

not certified by peer review) is the author/funder, who has granted bioRxiv a license to display the preprint in perpetuity. It is made available under aCC-BY 4.0 International license.

Zhao Z, Rubin EM, Korlach J, Pennacchio LA, Roberts RJ. 2016. The epigenomic 650 landscape of prokaryotes. PLOS Genet. 12(2):e1005854.

Blyn LB, Braaten BA, Low DA. 1990. Regulation of pap pilin phase variation by a mechanism involving differential dam methylation states. The EMBO Journal. 9 (12):4045-4054.

Bohlin J, Skjerve E, Ussery DW. 2008. Investigations of Oligonucleotide Usage Variance Within and Between Prokaryotes. PLOS Computational Biology. 4(4):e1000057. Publisher: Public Library of Science.

Braaten BA, Nou X, Kaltenbach LS, Low DA. 1994. Methylation patterns in pap regulatory DNA control pyelonephritis-associated pili phase variation in E. coli. Cell. 76(3):577-588.

Casadesús J. 2016. Bacterial DNA Methylation and Methylomes. Advances in Experimental Medicine and Biology. 945:35-61.

Casadesús J Low D. 2006. Epigenetic Gene Regulation in the Bacterial World. Microbiology and Molecular Biology Reviews. 70(3):830-856.

Casadesús J Low DA. 2013. Programmed Heterogeneity: Epigenetic Mechanisms in Bacteria. Journal of Biological Chemistry. 288(20):13929-13935.

666 Charlesworth D, Barton NH, Charlesworth B. 2017. The sources of adaptive variation. Proceedings of the Royal Society of London B: Biological Sciences. 284(1855).

668 Clark TA, Murray IA, Morgan RD, Kislyuk AO, Spittle KE, Boitano M, Fomenkov A, Roberts RJ, Korlach J. 2012. Characterization of DNA methyltransferase specificities 670 using single-molecule, real-time DNA sequencing. Nucleic Acids Research. 40(4): e29-e29.

672 Coffin SR Reich NO. 2008. Modulation of Escherichia coli DNA Methyltransferase 
bioRxiv preprint doi: https://doi.org/10.1101/822080; this version posted March 11, 2021. The copyright holder for this preprint (which was

not certified by peer review) is the author/funder, who has granted bioRxiv a license to display the preprint in perpetuity. It is made available under aCC-BY 4.0 International license.

Epigenetics and adaptation

Activity by Biologically Derived GATC-flanking Sequences. Journal of Biological 674 Chemistry. 283(29):20106-20116.

Cortijo S, Wardenaar R, Colomé-Tatché M, Gilly A, Etcheverry M, Labadie K, Cail676 lieux E, Hospital F, Aury JM, Wincker P, Roudier F, Jansen RC, Colot V, Johannes F. 2014. Mapping the epigenetic basis of complex traits. Science. 343(6175):11451148.

Danchin E, Charmantier A, Champagne FA, Mesoudi A, Pujol B, Blanchet S. 2011. Beyond DNA: integrating inclusive inheritance into an extended theory of evolution. Nat Rev Genet. 12(7):475-486.

Danchin E, Pocheville A, Rey O, Pujol B, Blanchet S. 2019. Epigenetically facilitated mutational assimilation: epigenetics as a hub within the inclusive evolutionary synthesis. Biological Reviews of the Cambridge Philosophical Society. 94(1):259-282.

Day T Bonduriansky R. 2011. A unified approach to evolutionary consequences of genetic and nongenetic inheritance. American Naturalist. 178:E18-E36.

Dubin MJ, Zhang P, Meng D, Remigereau MS, Osborne EJ, Paolo Casale F, Drewe P, Kahles A, Jean G, Vilhjálmsson B, Jagoda J, Irez S, Voronin V, Song Q, Long Q, Rätsch G, Stegle O, Clark RM, Nordborg M. 2015. DNA methylation in Arabidopsis has a genetic basis and shows evidence of local adaptation. eLife. 4:e05255.

Flyg C, Kenne K, Boman HG. 1980. Insect pathogenic properties of Serratia marcescens: phage-resistant mutants with a decreased resistance to Cecropia immunity and a decreased virulence to Drosophila. Journal of General Microbiology. 120(1): $173-181$.

Gao F, Luo H, Zhang CT. 2012. DoriC 5.0: an updated database of oriC regions in both bacterial and archaeal genomes. Nucleic Acids Research. 41(D1):D90-D93. 
bioRxiv preprint doi: https://doi.org/10.1101/822080; this version posted March 11, 2021. The copyright holder for this preprint (which was

not certified by peer review) is the author/funder, who has granted bioRxiv a license to display the preprint in perpetuity. It is made available under aCC-BY 4.0 International license.

Epigenetics and adaptation

Grimont PAD Grimont F. 1978. The genus Serratia. Annual Review of Microbiology. $32(1): 221-248$.

Hagmann J, Becker C, Müller J, Stegle O, Meyer RC, Wang G, Schneeberger K, Fitz J, Altmann T, Bergelson J, Borgwardt K, Weigel D. 2015. Century-scale methylome stability in a recently diverged Arabidopsis thaliana lineage. PLoS Genetics. 11(1): e1004920.

Hattman S, Brooks JE, Masurekar M. 1978. Sequence specificity of the P1 modification methylase (M.Eco P1) and the DNA methylase (M.Eco dam) controlled by the Escherichia coli dam gene. Journal of Molecular Biology. 126(3):367-380.

Jablonka E Raz G. 2009. Transgenerational epigenetic inheritance: prevalence, mechanisms, and implications for the study of heredity and evolution. Quarterly Review of Biology. 84:131-176.

Jiang C, Mithani A, Belfield EJ, Mott R, Hurst LD, Harberd NP. 2014. Environmentally responsive genome-wide accumulation of de novo Arabidopsis thaliana mutations and epimutations. Genome Research. 24(11):1821-1829.

Jones P, Binns D, Chang HY, Fraser M, Li W, McAnulla C, McWilliam H, Maslen J, Mitchell A, Nuka G, Pesseat S, Quinn AF, Sangrador-Vegas A, Scheremetjew M, Yong SY, Lopez R, Hunter S. 2014. InterProScan 5: genome-scale protein function classification. Bioinformatics. 30(9):1236-1240.

Kaminska R van der Woude MW. 2010. Establishing and maintaining sequestration of Dam target sites for phase variation of agn43 in Escherichia coli. Journal of Bacteriology. 192(7):1937-1945.

Ketola T, Mikonranta L, Zhang J, Saarinen K, Örmälä AM, Friman VP, Mappes J, Laakso J. 2013. Fluctuating temperature leads to evolution of thermal generalism and preadaptation to novel environments. Evolution. 67:2936-2944. 
bioRxiv preprint doi: https://doi.org/10.1101/822080; this version posted March 11, 2021. The copyright holder for this preprint (which was

not certified by peer review) is the author/funder, who has granted bioRxiv a license to display the preprint in perpetuity. It is made available under aCC-BY 4.0 International license.

Epigenetics and adaptation

722 Kronholm I Collins S. 2016. Epigenetic mutations can both help and hinder adaptive evolution. Molecular Ecology. 25:1856-1868.

724 Kronholm I, Bassett A, Baulcombe D, Collins S. 2017. Epigenetic and genetic contributions to adaptation in Chlamydomonas. Molecular Biology and Evolution. 34(9): $2285-2306$.

Lenski RE, Rose MR, Simpson SC, Tadler SC. 1991. Long-Term Experimental Evolution in Escherichia coli. I. Adaptation and Divergence During 2,000 Generations. The American Naturalist. 138(6):1315-1341.

Li H, Handsaker B, Wysoker A, Fennell T, Ruan J, Homer N, Marth G, Abecasis G, Durbin R, 1000 Genome Project Data Processing Subgroup. 2009. The Sequence Alignment/Map format and SAMtools. Bioinformatics (Oxford, England). 25(16): 2078-2079.

McIntyre ABR, Alexander N, Grigorev K, Bezdan D, Sichtig H, Chiu CY, Mason CE. 2019. Single-molecule sequencing detection of N 6-methyladenine in microbial reference materials. Nature Communications. 10(1):1-11. Number: 1 Publisher: Nature Publishing Group.

Murray IA, Clark TA, Morgan RD, Boitano M, Anton BP, Luong K, Fomenkov A, Turner SW, Korlach J, Roberts RJ. 2012. The methylomes of six bacteria. Nucleic Acids Research. 40(22):11450-11462.

Murray IA, Morgan RD, Luyten Y, Fomenkov A, Corrêa IR, Dai N, Allaw MB, Zhang X, Cheng X, Roberts RJ. 2018. The non-specific adenine DNA methyltransferase M.EcoGII. Nucleic Acids Research. 46(2):840-848.

Olivenza DR, Nicoloff H, Sánchez-Romero MA, Cota I, Andersson DI, Casadesús J. 2019. A portable epigenetic switch for bistable gene expression in bacteria. Scientific Reports. 9(1):1-9. Number: 1 Publisher: Nature Publishing Group. 
bioRxiv preprint doi: https://doi.org/10.1101/822080; this version posted March 11, 2021. The copyright holder for this preprint (which was

not certified by peer review) is the author/funder, who has granted bioRxiv a license to display the preprint in perpetuity. It is made available under aCC-BY 4.0 International license.

Epigenetics and adaptation

Oshima T, Wada C, Kawagoe Y, Ara T, Maeda M, Masuda Y, Hiraga S, Mori H. 2002.

Genome-wide analysis of deoxyadenosine methyltransferase-mediated control of gene expression in Escherichia coli. Molecular Microbiology. 45(3):673-695.

Ostendorf T, Cherepanov P, Vries Jd, Wackernagel W. 1999. Characterization of a dam mutant of Serratia marcescens and nucleotide sequence of the dam region. Journal of Bacteriology. 181(13):3880-3885.

Pride DT, Meinersmann RJ, Wassenaar TM, Blaser MJ. 2003. Evolutionary implications of microbial genome tetranucleotide frequency biases. Genome Research. 13 (2):145-158.

Ratel D, Ravanat JL, Berger F, Wion D. 2006. N6-methyladenine: the other methylated base of DNA. Bioessays. 28(3):309-315.

758 Rhoads A Au KF. 2015. PacBio Sequencing and Its Applications. Genomics, Proteomics ES Bioinformatics. 13(5):278-289.

760 Riva A, Delorme MO, Chevalier T, Guilhot N, Hénaut C, Hénaut A. 2004. The difficult interpretation of transcriptome data: the case of the GATC regulatory network. Computational Biology and Chemistry. 28(2):109-118.

Roberts RJ, Vincze T, Posfai J, Macelis D. 2015. REBASE-a database for DNA restriction and modification: enzymes, genes and genomes. Nucleic Acids Research. 43(D1):D298-D299. Publisher: Oxford Academic.

766 Rocha EP, Viari A, Danchin A. 1998. Oligonucleotide bias in Bacillus subtilis: general trends and taxonomic comparisons. Nucleic Acids Research. 26(12):2971-2980.

768 Sánchez-Romero MA, Cota I, Casadesús J. 2015. DNA methylation in bacteria: from the methyl group to the methylome. Current Opinion in Microbiology. 25:9-16.

770 Taboada B, Estrada K, Ciria R, Merino E. 2018. Operon-mapper: a web server for 
precise operon identification in bacterial and archaeal genomes. Bioinformatics. 34 $772 \quad(23): 4118-4120$.

Tatusova T, DiCuccio M, Badretdin A, Chetvernin V, Nawrocki EP, Zaslavsky L, Lomsadze A, Pruitt KD, Borodovsky M, Ostell J. 2016. NCBI prokaryotic genome annotation pipeline. Nucleic Acids Research. 44(14):6614-6624.

776 Tavazoie S Church GM. 1998. Quantitative whole-genome analysis of DNA-protein interactions by in vivo methylase protection in E. coli. Nature Biotechnology. 16(6): $566-571$.

van der Graaf A, Wardenaar R, Neumann DA, Taudt A, Shaw RG, Jansen RC, Schmitz RJ, Colomé-Tatché M, Johannes F. 2015. Rate, spectrum, and evolutionary dynamics of spontaneous epimutations. Proceedings of the National Academy of Sciences. 112(21):6676-6681.

van der Woude M, Hale WB, Low DA. 1998. Formation of DNA Methylation Patterns: Nonmethylated GATC Sequences in gut and pap Operons. Journal of Bacteriology. 180(22):5913-5920.

Veening JW, Smits WK, Kuipers OP. 2008. Bistability, epigenetics, and bet-hedging in bacteria. Annual Review of Microbiology. 62(1):193-210.

Wallecha A, Munster V, Correnti J, Chan T, van der Woude M. 2002. Dam- and OxyR-dependent phase variation of agn43: essential elements and evidence for a new role of DNA methylation. Journal of Bacteriology. 184(12):3338-3347.

Wibowo A, Becker C, Marconi G, Durr J, Price J, Hagmann J, Papareddy R, Putra H, Kageyama J, Becker J, Weigel D, Gutierrez-Marcos J. 2016. Hyperosmotic stress memory in Arabidopsis is mediated by distinct epigenetically labile sites in 794 the genome and is restricted in the male germline by DNA glycosylase activity. eLife. 5:e13546. 
bioRxiv preprint doi: https://doi.org/10.1101/822080; this version posted March 11, 2021. The copyright holder for this preprint (which was not certified by peer review) is the author/funder, who has granted bioRxiv a license to display the preprint in perpetuity. It is made available under aCC-BY 4.0 International license.

796 Winter DJ. 2017. rentrez: an R package for the NCBI eUtils API. The $R$ Journal. 9: $520-526$. 


\section{Supplementary Tables}

\begin{tabular}{|c|c|c|c|c|c|}
\hline GO ID & GO term & Annotated & Significant & Expected & $\mathrm{P}$-value \\
\hline \multicolumn{6}{|l|}{ Yield at $24^{\circ} \mathrm{C}$} \\
\hline GO:1901607 & $\begin{array}{c}\text { Alpha-amino acid biosynthetic } \\
\text { process }\end{array}$ & 10 & 5 & 1.24 & 0.003 \\
\hline GO:0048519 & $\begin{array}{c}\text { Negative regulation of biological } \\
\text { process }\end{array}$ & 20 & 4 & 2.47 & 0.015 \\
\hline GO:0044272 & $\begin{array}{l}\text { Sulfur compound biosynthetic } \\
\text { process }\end{array}$ & 8 & 3 & 0.99 & 0.063 \\
\hline \multicolumn{6}{|l|}{ Yield at $38^{\circ} \mathrm{C}$} \\
\hline GO:0048523 & $\begin{array}{c}\text { Negative regulation of cellular } \\
\text { process }\end{array}$ & 17 & 3 & 2.61 & 0.025 \\
\hline GO:0001510 & RNA methylation & 5 & 3 & 0.77 & 0.027 \\
\hline GO:0006508 & Proteolysis & 5 & 3 & 0.77 & 0.027 \\
\hline GO:1905039 & $\begin{array}{c}\text { Carboxylic acid transmembrane } \\
\text { transport }\end{array}$ & 5 & 3 & 0.77 & 0.027 \\
\hline GO:0065009 & $\begin{array}{l}\text { Regulation of molecular } \\
\text { function }\end{array}$ & 6 & 3 & 0.92 & 0.048 \\
\hline
\end{tabular}

Supplementary Table S1: Results of the gene ontology (GO) enrichment tests based on the association between m6A methylation and phenotypes. Partially methylated m6A epiloci exhibiting a methylation fraction range $\geq 0.2$ across sequenced samples were considered and the overlapping or closest $(\leq 500 \mathrm{bp})$ downstream gene, if any, was assigned to each of those epiloci. For each phenotypic trait and each epiloci, Spearman's $\rho$ was calculated between the trait values and the epiloci methylated fractions, and the corresponding uncorrected p-value was assigned to the gene associated to the epiloci. We then defined the set of genes of interest based on a threshold of Spearman's $p=0.05$ and performed a GO enrichment test using topGO with the Fisher's exact test and the "weight01" algorithm (Alexa et al., 2006; Alexa and Rahnenfuhrer, 2020). GO terms with enrichment test $p \leq 0.1$ are reported for each trait (table continued on next page). 


\begin{tabular}{|c|c|c|c|c|c|}
\hline GO ID & GO term & Annotated & Significant & Expected & $\mathrm{P}$-value \\
\hline \multicolumn{6}{|c|}{ Yield with ciliate } \\
\hline GO:0048523 & $\begin{array}{c}\text { Negative regulation of cellular } \\
\text { process }\end{array}$ & 17 & 3 & 2.29 & 0.019 \\
\hline GO:0006310 & DNA recombination & 6 & 3 & 0.81 & 0.034 \\
\hline GO:0065009 & $\begin{array}{l}\text { Regulation of molecular } \\
\text { function }\end{array}$ & 6 & 3 & 0.81 & 0.034 \\
\hline GO:0006974 & $\begin{array}{c}\text { Cellular response to DNA } \\
\text { damage stimulus }\end{array}$ & 17 & 5 & 2.29 & 0.062 \\
\hline \multicolumn{6}{|l|}{ Yield with virus } \\
\hline GO:0048523 & $\begin{array}{l}\text { Negative regulation of cellular } \\
\text { process }\end{array}$ & 17 & 5 & 1.72 & 0.009 \\
\hline GO:0065009 & $\begin{array}{l}\text { Regulation of molecular } \\
\text { function }\end{array}$ & 6 & 3 & 0.61 & 0.015 \\
\hline GO:0007154 & Cell communication & 14 & 4 & 1.42 & 0.026 \\
\hline GO:0006790 & $\begin{array}{l}\text { Sulfur compound metabolic } \\
\text { process }\end{array}$ & 12 & 3 & 1.21 & 0.028 \\
\hline GO:0006974 & $\begin{array}{c}\text { Cellular response to DNA } \\
\text { damage stimulus }\end{array}$ & 17 & 4 & 1.72 & 0.079 \\
\hline GO:0006508 & Proteolysis & 5 & 2 & 0.51 & 0.081 \\
\hline GO:0043648 & $\begin{array}{c}\text { Dicarboxylic acid metabolic } \\
\text { process }\end{array}$ & 5 & 2 & 0.51 & 0.081 \\
\hline GO:1901564 & $\begin{array}{l}\text { Organonitrogen compound } \\
\text { metabolic process }\end{array}$ & 66 & 8 & 6.67 & 0.099 \\
\hline
\end{tabular}

(Continued from previous page and on next page.) 


\begin{tabular}{|c|c|c|c|c|c|}
\hline GO ID & GO term & Annotated & Significant & Expected & P-value \\
\hline \multicolumn{6}{|c|}{ Growth rate at $24^{\circ} \mathrm{C}$} \\
\hline GO:0044282 & Small molecule catabolic process & 14 & 4 & 1.26 & 0.017 \\
\hline GO:0070887 & $\begin{array}{c}\text { Cellular response to chemical } \\
\text { stimulus }\end{array}$ & 7 & 3 & 0.63 & 0.018 \\
\hline GO:0015672 & $\begin{array}{c}\text { Monovalent inorganic cation } \\
\text { transport }\end{array}$ & 6 & 2 & 0.54 & 0.093 \\
\hline GO:0051301 & Cell division & 6 & 2 & 0.54 & 0.093 \\
\hline GO:0006081 & $\begin{array}{c}\text { Cellular aldehyde metabolic } \\
\text { process }\end{array}$ & 6 & 2 & 0.54 & 0.093 \\
\hline
\end{tabular}

Growth rate at $31{ }^{\circ} \mathrm{C}$

\begin{tabular}{|c|c|c|c|c|c|}
\hline \\
\hline GO:0042180 & $\begin{array}{c}\text { Cellular ketone metabolic } \\
\text { process }\end{array}$ & 5 & 3 & 0.41 & 0.004 \\
\hline GO:0006081 & $\begin{array}{c}\text { Cellular aldehyde metabolic } \\
\text { process }\end{array}$ & 6 & 3 & 0.49 & 0.008 \\
\hline GO:0016051 & $\begin{array}{c}\text { Carbohydrate biosynthetic } \\
\text { process }\end{array}$ & 14 & 3 & 1.15 & 0.035 \\
\hline GO:0051301 & Cell division & 6 & 2 & 0.49 & 0.080 \\
\hline GO:0006793 & Phosphorus metabolic process & 32 & 3 & 2.64 & 0.085 \\
\hline GO:0044282 & Small molecule catabolic process & 14 & 3 & 1.15 & 0.097 \\
\hline \multicolumn{6}{|c|}{ Growth rate at $38^{\circ} \mathrm{C}$} \\
\hline GO:0044085 & Cellular component biogenesis & 23 & 5 & 1.98 & 0.053 \\
\hline GO:0030031 & Cell projection assembly & 5 & 2 & 0.43 & 0.061 \\
\hline GO:0042180 & $\begin{array}{c}\text { Cellular ketone metabolic } \\
\text { process }\end{array}$ & 5 & 2 & 0.43 & 0.061 \\
\hline GO:0044238 & Primary metabolic process & 149 & 15 & 12.84 & 0.076 \\
\hline GO:1903509 & $\begin{array}{c}\text { Liposaccharide metabolic } \\
\text { process }\end{array}$ & 10 & 2 & 0.86 & 0.085 \\
\hline GO:0006396 & RNA processing & 11 & 2 & 0.95 & 0.086 \\
\hline
\end{tabular}

(Continued from previous page and on next page.) 


\begin{tabular}{|c|c|c|c|c|c|}
\hline GO ID & GO term & Annotated & Significant & Expected & $\mathrm{P}$-value \\
\hline \multicolumn{6}{|c|}{ Growth rate with DTT } \\
\hline GO:0006091 & $\begin{array}{l}\text { Generation of precursor } \\
\text { metabolites and energy }\end{array}$ & 12 & 4 & 1.35 & 0.020 \\
\hline GO:0006518 & Peptide metabolic process & 14 & 3 & 1.57 & 0.035 \\
\hline GO:0009103 & $\begin{array}{l}\text { Lipopolysaccharide biosynthetic } \\
\text { process }\end{array}$ & 8 & 3 & 0.90 & 0.049 \\
\hline GO:0044237 & Cellular metabolic process & 163 & 23 & 18.31 & 0.076 \\
\hline GO:0009314 & Response to radiation & 10 & 3 & 1.12 & 0.089 \\
\hline GO:0006979 & Response to oxidative stress & 5 & 2 & 0.56 & 0.099 \\
\hline GO:0072528 & $\begin{array}{l}\text { Pyrimidine-containing } \\
\text { compound biosynthetic process }\end{array}$ & 5 & 2 & 0.56 & 0.099 \\
\hline \multicolumn{6}{|c|}{ Growth rate with ciliate } \\
\hline GO:0072528 & $\begin{array}{c}\text { Pyrimidine-containing } \\
\text { compound biosynthetic process }\end{array}$ & 5 & 3 & 0.77 & 0.027 \\
\hline GO:0009263 & $\begin{array}{l}\text { Deoxyribonucleotide } \\
\text { biosynthetic process }\end{array}$ & 5 & 3 & 0.77 & 0.027 \\
\hline GO:0006260 & DNA replication & 6 & 3 & 0.92 & 0.048 \\
\hline GO:0006259 & DNA metabolic process & 13 & 5 & 2.00 & 0.070 \\
\hline \multicolumn{6}{|c|}{ Growth rate with virus } \\
\hline GO:0006508 & Proteolysis & 5 & 3 & 0.47 & 0.006 \\
\hline GO:0009314 & Response to radiation & 10 & 3 & 0.94 & 0.068 \\
\hline GO:0006400 & TRNA modification & 5 & 2 & 0.47 & 0.071 \\
\hline GO:0006091 & $\begin{array}{l}\text { Generation of precursor } \\
\text { metabolites and energy }\end{array}$ & 12 & 4 & 1.12 & 0.090 \\
\hline GO:0015980 & $\begin{array}{l}\text { Energy derivation by oxidation } \\
\text { of organic compounds }\end{array}$ & 6 & 2 & 0.56 & 0.092 \\
\hline
\end{tabular}

(Continued from previous page.) 


\section{Supplementary Figures}

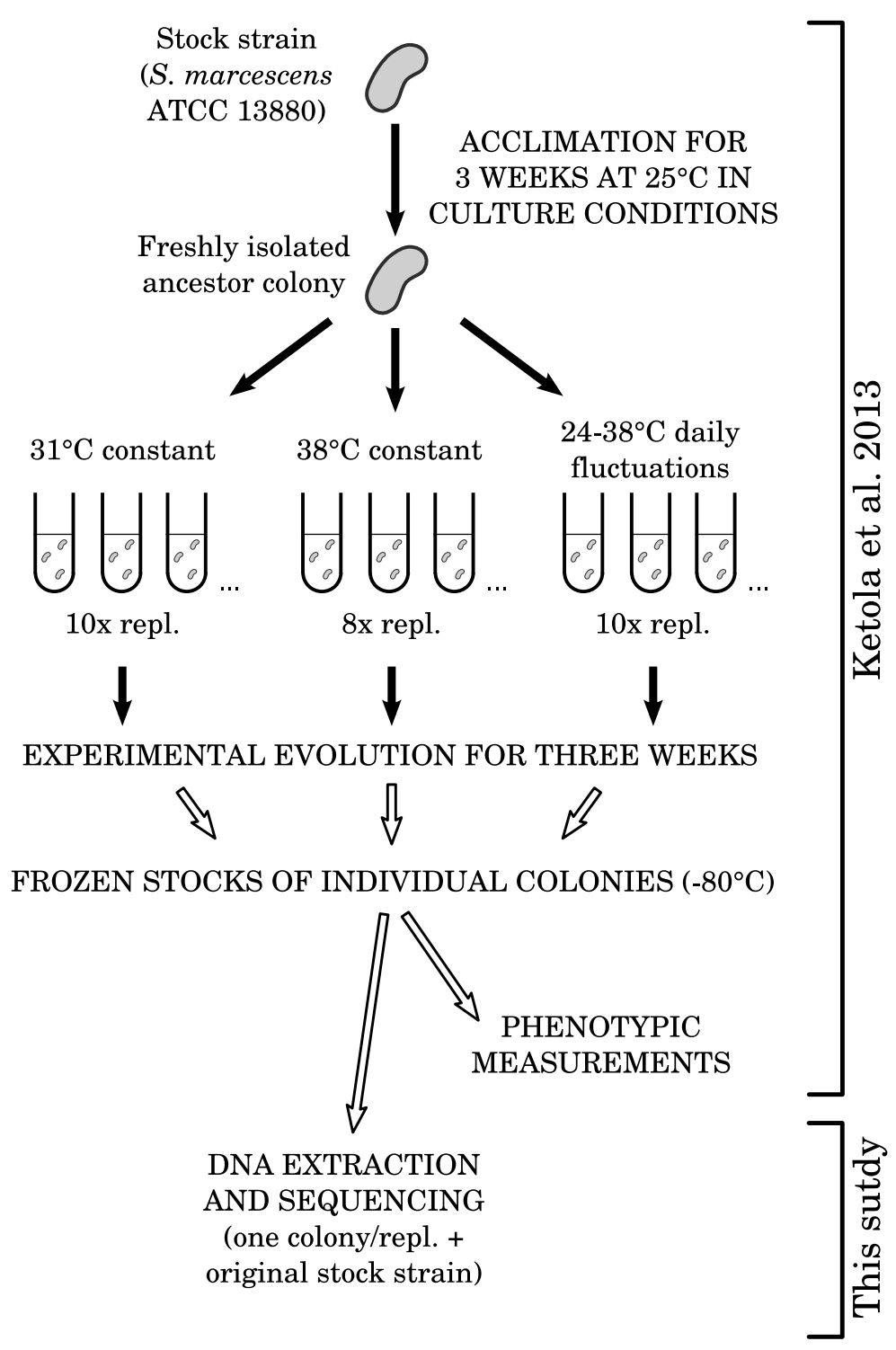

Supplementary Figure S1: Setup of the evolution experiment from which sequenced clones were isolated. Open arrows after experimental evolution indicates steps where evolved clones were grown under common garden conditions. 
bioRxiv preprint doi: https://doi.org/10.1101/822080; this version posted March 11, 2021. The copyright holder for this preprint (which was not certified by peer review) is the author/funder, who has granted bioRxiv a license to display the preprint in perpetuity. It is made available under aCC-BY 4.0 International license.

Epigenetics and adaptation

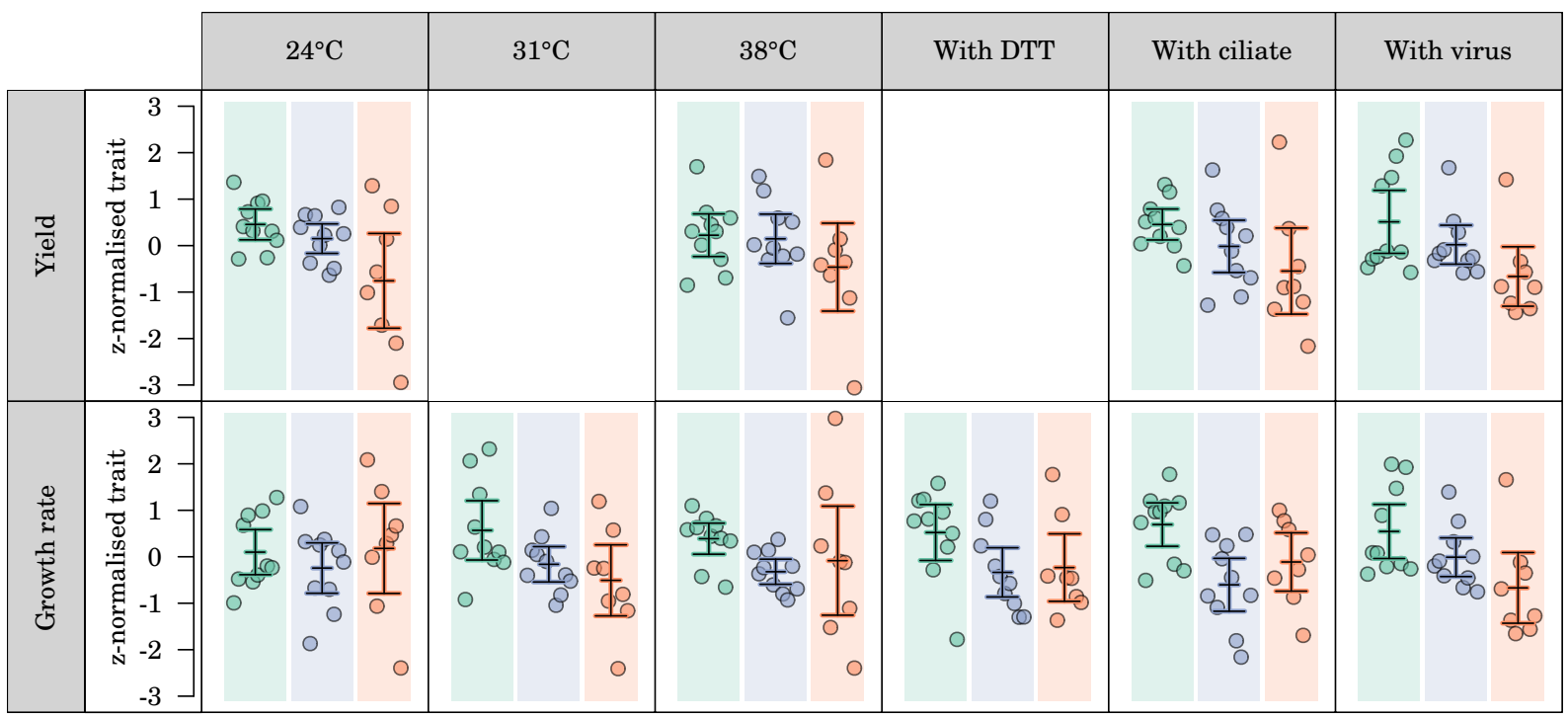

Evolutionary treatments: $\square 24-38^{\circ} \mathrm{C} \quad \square 31^{\circ} \mathrm{C} \quad \square 38^{\circ} \mathrm{C}$

Supplementary Figure S2: Phenotypic traits measured in Ketola et al. (2013) and used in the present study. Each data point represents one evolved strain sequenced in this study. Bars and whiskers are mean values $+/-1.96 \times$ s.e. for all sequenced strains within an evolutionary treatment.

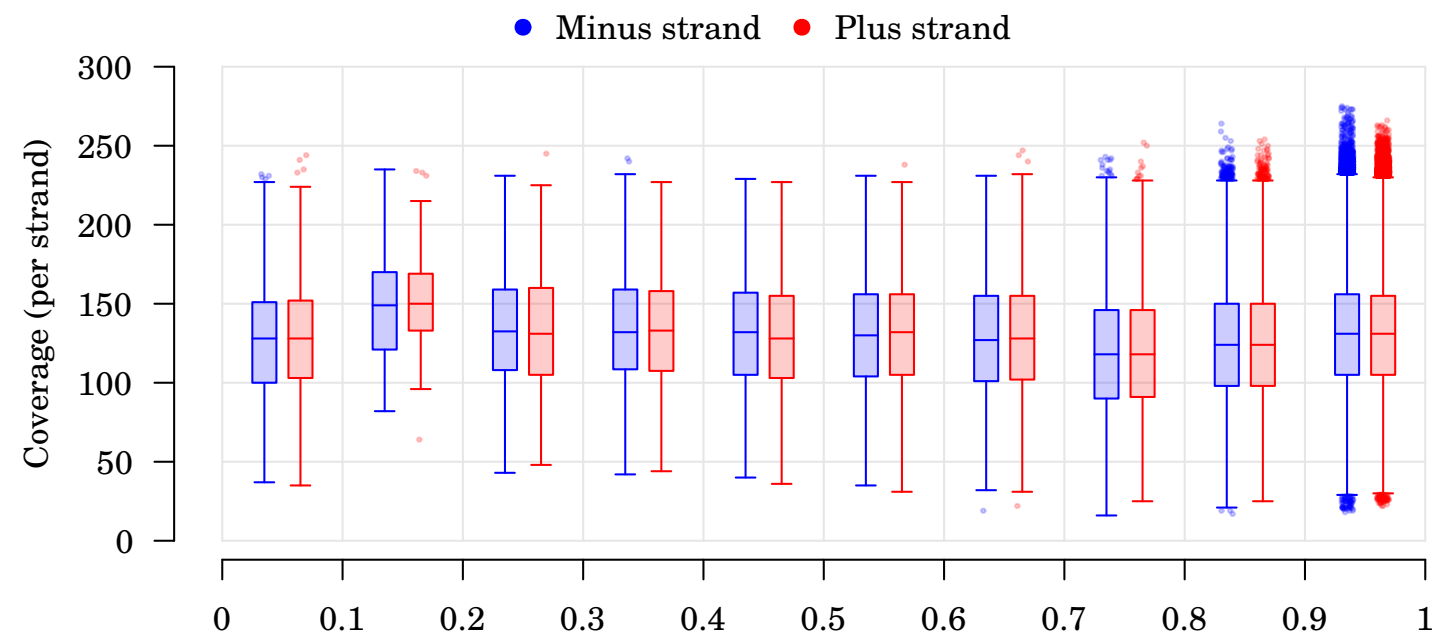

Methylated fraction of adenosines in GATC

Supplementary Figure S3: Relationship between coverage and estimated fraction of methylated adenines in GATC motifs. All adenines present in GATC motifs, from all sequenced strains, are included. Data is binned by intervals of methylated fraction of 0.1 width, as indicated on the $x$ axis. There is no correlation between coverage and estimated methylated fraction (Spearman's $\rho=-0.01$ ). However, the slight increase in average coverage for the $(0.1,0.2)$ methylated fractions compared to the $(0,0.1)$ fractions suggests that at very low methylation levels (below 0.2), higher coverage is needed to estimate a methylated fraction other than 0 . 

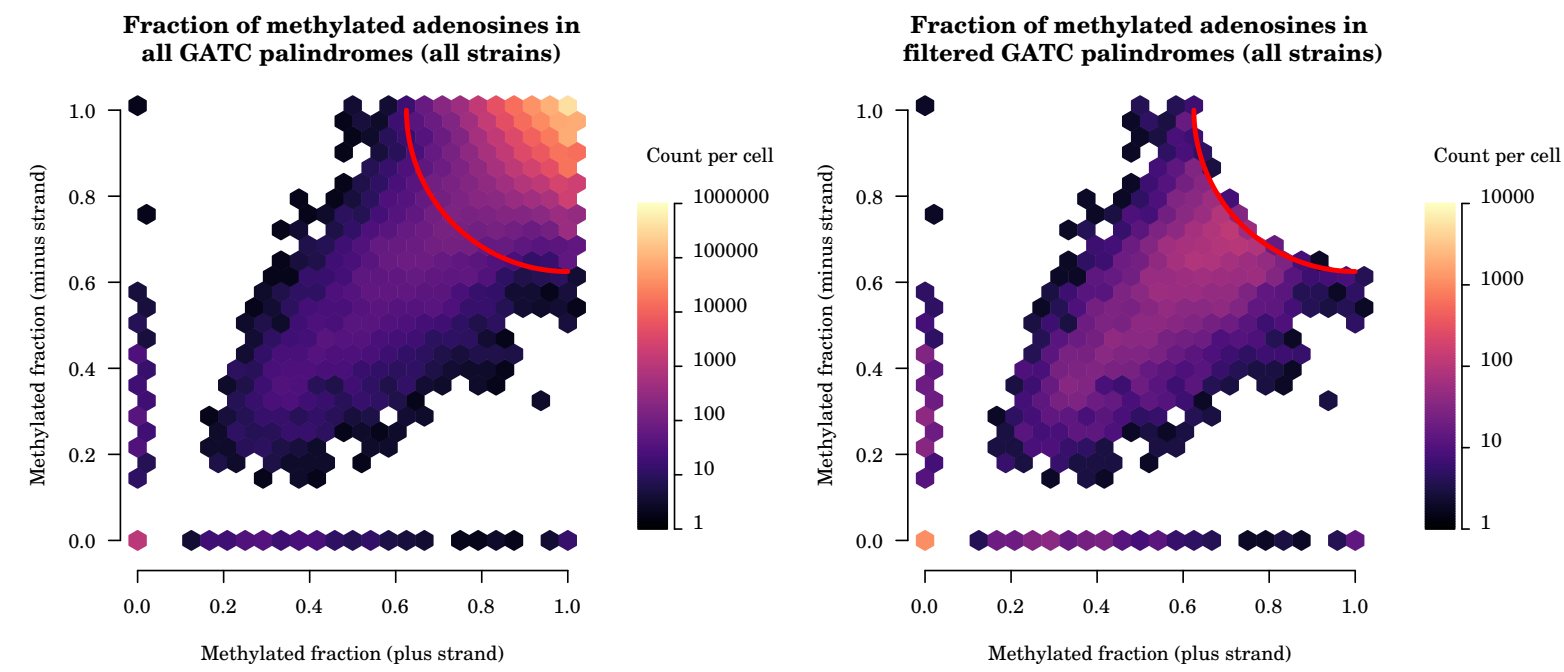

Supplementary Figure S4: Detection of partially methylated GATC loci. Distribution of methylated fractions of adenines on boths DNA strands for GATC palindromes (showing data for all strains together). Left panel, all GATC palindromes shown; right panel, only GATC palindromes qualified as low methylation sites shown. The red arc in the left panel delimits the observations which are less four times the average quadratic distance to full methylation (point at $(1,1)$ ) away from full methylation. GATC palindromes are considered as low methylation sites if they lay outside this area (right panel). 
bioRxiv preprint doi: https://doi org/101101/822080; this version posted March 11,2021. The copyright holder for this preprint (which was not certified by peer review) is the author/funder, who has granted bioRxiv a license to display the preprint in perpetuity. It is made available under aCC-BY 4.0 International license.

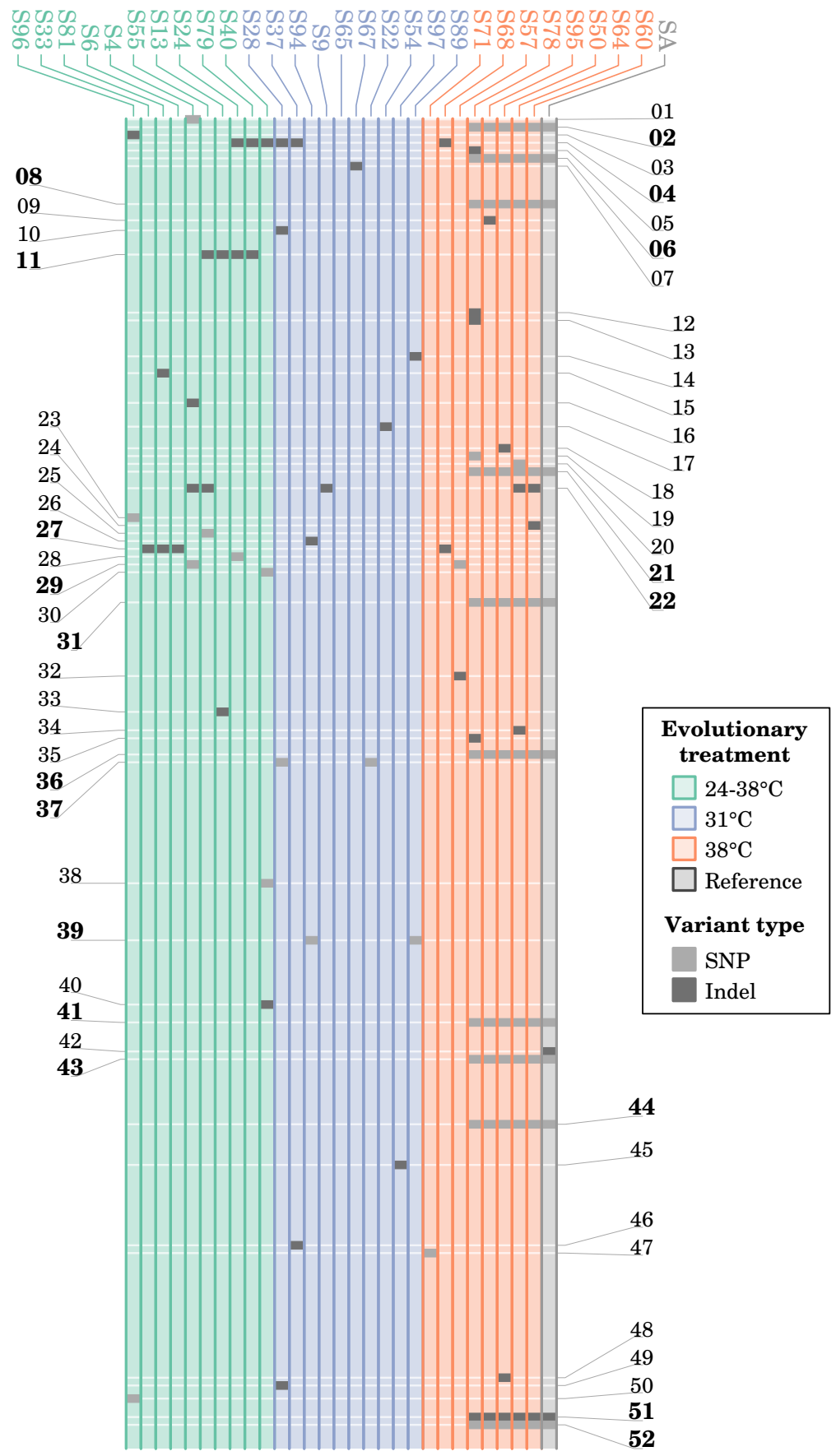

Supplementary Figure S5: Distribution of genetic variants among sequenced S. marcescens clones. Each vertical lane represents the chromosome sequence of one clone. The locations along the chromosome are approximate in order to keep close loci visually distinct. Minor alleles of genetic variants are depicted. The numerical IDs of variants observed in more than one genome are shown in bold. Details about each variant are available in Table 1. 